\title{
Biological Invasion Theories: Merging Perspectives from Population, Community and Ecosystem Scales
}

Chabrerie O. ${ }^{1}$, Massol F. ${ }^{2}$, Facon B. ${ }^{3}$, Thevenoux R. ${ }^{4,5}$, Hess M. $., 7,8$, Ulmer R. ${ }^{1}$, Pantel J.H. ${ }^{9}$, Braschi J. ${ }^{6,10}$, Amsellem L. ${ }^{11}$, Baltora-Rosset S. ${ }^{1}$, Tasiemski A. ${ }^{2}$, Grandjean F. ${ }^{12}$, Gibert P. ${ }^{13}$, Chauvat M. ${ }^{14}$, Affre L. ${ }^{6}$, Thiébaut G. ${ }^{15}$, Viard F. ${ }^{16}$, Forey E. ${ }^{14}$, Folcher L. ${ }^{4}$, Boivin T. ${ }^{17}$, Buisson E. ${ }^{5}$, Richardson D.M. ${ }^{18}$, Renault D. ${ }^{15,19}$

\section{$\underline{\text { Affiliations }}$}

1 Université de Picardie Jules Verne, UMR 7058 CNRS EDYSAN, 1 rue des Louvels, 80037 Amiens Cedex 1, France

2 Univ. Lille, CNRS, Inserm, CHU Lille, Institut Pasteur de Lille, U1019 - UMR 8204 CIIL - Center for Infection and Immunity of Lille, F-59000 Lille, France

${ }^{3}$ INRA, UMR PVBMT, Saint Pierre, France

4 ANSES - Agence nationale de sécurité sanitaire de l'alimentation, de l'environnement et du travail, Laboratoire de la santé des végétaux - Unité de nématologie, F-35653 Le Rheu, France

${ }^{5}$ IGEPP, INRA, Agrocampus Ouest, Université de Rennes 1, 35650, Le Rheu, France

${ }^{6}$ Institut Méditerranéen de Biodiversité et d'Ecologie marine et continentale (IMBE), UMR: Aix Marseille Université, Avignon Université, CNRS, IRD, France

${ }^{7}$ Institut de recherche pour la conservation des zones humides méditerranéennes Tour du Valat, Le Sambuc, 13200 Arles, France

8 NGE-GUINTOLI, Saint-Etienne du Grès, Parc d'activités de Laurade - BP22, 13156 Tarascon Cedex, France

9 Department of Computer Science, Mathematics, and Environmental Science, The American University of Paris, 6 rue du Colonel Combes, 75007 Paris, France

10 Naturalia-Environnement, Ingénierie en écologie, 20 Rue Lawrence Durrell, 84140 Avignon, France

${ }^{11}$ Université de Lille, UMR CNRS 8198-Evolution, Ecology and Paleontology, F59650 Villeneuve d'Ascq, France.

12 Université de Poitiers, UMR CNRS 7267 EBI- Ecologie et Biologie des Interactions, équipe EES, 5 rue Albert Turpin, Bat B8-B35, TSA 51106, 86073 Poitiers Cedex 09, France

13 UMR 5558 CNRS - Université Claude Bernard Lyon 1, Biométrie et Biologie Evolutive, Bât. Gregor Mendel, 43 bd du 11 novembre 1918, 69622 VILLEURBANNE cedex, France 
${ }^{14}$ Normandie Université, UNIROUEN, IRSTEA, ECODIV, 76000 Rouen, France

15 Université de Rennes 1, UMR CNRS 6553 EcoBio, 263 Avenue du Gal Leclerc, CS 74205, 35042 Rennes Cedex, France

16 Sorbonne Université, CNRS, UMR 7144, Station Biologique de Roscoff, Place Georges Teissier, 29680 Roscoff, France

17 INRA, UR629 Écologie des Forêts Méditerranéennes, Centre de recherche ProvenceAlpes-Côte d'Azur, CS 40509, 84914 Avignon, France

18 Centre for Invasion Biology, Department of Botany and Zoology, Stellenbosch University, Matieland 7602, South Africa

${ }^{19}$ Institut Universitaire de France, 1 rue Descartes, 75231 Paris Cedex 05, France

\title{
Corresponding authors:
}

\section{David RENAULT}

Université de Rennes 1, UMR CNRS 6553 EcoBio, 263 Avenue du Gal Leclerc, CS 74205, 35042 Rennes Cedex, France

Email: david.renault@univ-rennes1.fr

\section{Olivier CHABRERIE}

Université de Picardie Jules Verne, UMR 7058 CNRS EDYSAN, 1 rue des Louvels, 80037 Amiens Cedex 1, France

Email: olivier.chabrerie@u-picardie.fr

\begin{abstract}
Biological invasions have reached an unprecedented level and the number of introduced species is still increasing worldwide. Despite major advances in invasion science, the determinants of success of introduced species, the magnitude and dimensions of their impact, and the mechanisms sustaining successful invasions are still debated. Empirical studies show divergent impacts of non-native populations on ecosystems and contrasting effects of biotic and abiotic factors on the dynamics of non-native populations; this is hindering the emergence of a unified theory of biological invasions. We propose a synthesis that merges perspectives from population, community, and ecosystem levels. Along a timeline of ecosystem transformation driven by non-native species, from
\end{abstract}


historical to human-modified ecosystems, we order invasion concepts and theories to clarify their chaining and relevance during each step of the invasion process. This temporal sorting of invasion concepts shows that each concept is relevant at a specific stage of the invasion. Concepts and empirical findings on non-native species may appear contradictory. However, we suggest that, when mapped onto an invasion timeline, they may be combined in a complementary way. An overall scheme is proposed to summarise the theoretical dynamics of ecosystems subjected to invasions. For any given case study, this framework provides a guide through the maze of theories and should help choose the appropriate concepts according to the stage of invasion.

Keywords: non-native populations; geographic expansion; invasiveness; invasibility; dispersal; phenotypic plasticity; evolution; historical ecosystem; hybrid ecosystem; novel ecosystem

\section{CONTENTS}

I. Introduction

II. Introduction and establishment of non-native populations in historical ecosystems

(1) Pre-introduction events: the traits of non-native populations in their native ranges and transport

(2) First contacts of non-native organisms with their recipient ecosystems

(3) Key determinants of species invasiveness

(4) Biotic resistance as guardian of historical ecosystems

(5) Invasibility of habitats and ecosystems

(6) Environmental heterogeneity and habitat disturbance favour invasibility

(7) Life history strategies of the colonizers along an invasion course

(8) Low effects of non-native populations on native diversity in the early stages of introduction

III. Expansion of non-native populations and modifications of assembly rules in hybrid ecosystems

(1) Paradoxical success of genetically impoverished populations

(2) Evolution of traits in non-native populations

(3) Unbridled dispersal at the invasion front

(4) Role shifting from non-native passenger to non-native driver of ecosystem changes

(5) Expansion of non-native populations associated with novel biological weapons and defences 
(6) Non-native species are playing with their natural enemies during the expansion stage

(7) A delayed invasion but an invasion debt to be finally paid

(8) Climate change as a major driver of non-native populations expansion

IV. Rapid evolution of non-native populations and emerging properties in novel ecosystems

(1) Admixture and hybridization of non-native populations

(2) New species, new rules, new properties, new ecosystems

V. A functional perspective of invasions and future directions

VI. Conclusions

VII. References 


\section{Introduction}

The number of invasive non-native populations, defined as organisms that are introduced to a region through human activity, establish self-perpetuating populations, and spread over substantial distances from introduction sites (Richardson, Pyšek \& Carlton, 2011), is increasing globally (Seebens et al., 2017). Biological invasions are now widely recognized as a major component of global change that can alter ecosystem functioning (Murphy \& Romanuk, 2014; Mollot, Pantel \& Romanuk, 2017), and redefine biogeography at a worldwide scale (Capinha et al., 2015). Concomitantly, invasion biology has grown into one of the most vibrant fields of ecology (Simberloff, 2004; Simberloff \& Vitule, 2014). The field has accumulated a multitude of hypotheses and theories (Catford, Jansson \& Nilsson, 2009), some of which at first sight may appear to be redundant, complementary, or contradictory (Enders, Hütt \& Jeschke, 2018). Despite attempts to develop a unified framework (Hallett, 2006; Catford et al., 2009; Blackburn et al., 2011; Dick et al., 2017), the plethora of proposed concepts, theories, and definitions makes it difficult to navigate this theoretical maze. As a result, choosing and applying the appropriate theory to a given case of invasion represents a major challenge. Nowadays, despite strong connections between ecological and evolutionary concepts of invasion biology (Facon et al., 2006; Vanderhoeven et al., 2010), an integrated view of the spatio-temporal dynamics of the invasion process is still lacking.

Most of the theories proposed so far to explain invasions are useful, and valid, at least partly, for a given species (or group of species), habitat, invasion stage, spatial or temporal scale. Meanwhile, given the huge evolutionary and functional diversity that exists in the global invasive biota, a single model that describes or profiles a "good invader" or a "successful invader" is clearly an unrealistic aim (Facon et al., 2006; Kueffer et al., 2013). Moreover, divergences between empirical evidence are frequently reported, as are discrepancies between theories and observations (Jeschke, Pyšek \& Richardson, 2012). Consequently, the main predictors driving differences in the magnitude of the invasion success in recipient communities and ecosystems are not understood in general.

Three challenging questions currently dominate the research agenda in invasion biology: (1) How can the exceptional success of some invasive populations in recipient environments be explained? (2) What effects do invasive populations have on local communities? (3) What will be the features of tomorrow's ecosystems? Work addressing these questions during the past two decades has mainly been focussed at population and ecosystem levels, with insights at the ecosystem level being increasing being sought when addressing these questions.

Here, we propose a synthesis that integrates perspectives on biological invasions at population, community and ecosystem levels to highlight the spatio-temporal and functional links between invasion theories at different stages of the introductionestablishment-naturalization-invasion continuum (sensu Richardson \& Pysek, 2006). While studies are mostly taxon-focused, we include all potentially invasive populations in all groups, and their interactions. Along a theoretical timeline from the importation of 
propagules to the transformation of ecosystems and ecosystem services driven by nonnative populations (Hobbs et al., 2009; Richardson \& Gaertner, 2013; Hobbs et al., 2014), we order concepts and theories related to invasions to picture their chaining and relevance during the sequential stages of the invasion process. Each concept and theory is emphasized with a short name in bold and can be retrieved along the invasion timeline presented in Figure 1. In so doing, we organize the variety of concepts associated with invasion processes and incorporate them into an innovative spatio-temporal framework. Our invasion timeline, besides allowing the positioning of events that play out over a range of time scales such as spatial sorting, alteration of ecological interactions, or evolution, opens valuable research questions on the functioning and fate of future ecosystems and their underlying services. This perspective better captures the range of transformations occurring at population, habitat and ecosystem levels, their interconnections and feedback loops. In particular, it emphasizes the importance of the temporal dynamics of invasion processes and the unintended effects they may have on the rest of the ecosystem.

\section{Introduction and establishment of non-native populations in historical ecosystems}

(1) Pre-introduction events: the traits of non-native populations in their native ranges and transport

One of the first keys of the success of non-native organisms' integration into historical ecosystems may be found in the features of populations and environments in the native range of the species (Renault et al., 2018).

Key adaptation events of non-native populations may occur at different steps of the invasion process (Rey et al., 2012). Most studies focus on evolutionary changes that occur following introduction to the recipient habitat (i.e., post-introduction adaptation scenario, Lee, Remfert \& Gelembiuk, 2003) or, more specifically at a primary site of invasion (Lombaert et al., 2010). Adaptation events that take place before introduction within the native range of the invader (i.e. prior-adaptation scenario) are less often considered. However, a preselection of traits responsible for the invasive character of a non-native population may occur in its native area (1: PRESE, Fig. 1) (Rey et al., 2012). This is particularly true when ecotypic variation exists in the native range. For instance, the invasion of Israel by the tropical ant Wasmannia auropunctata likely occurred after the sampling of a particularly cold-tolerant population at the southern limit of its native range (Rey et al., 2012). In addition, multiple introductions from different source populations are expected to increase invasion probability, as reported in the green crab Carcinus maenas whose northward expansion in the eastern North America may have been facilitated by a second independent introduction of a presumably cold-adapted ecotype from Europe (Jeffery et al., 2017; 2018). 
Similar ecological niches, or at least similar climatic environments, occur in many parts of the world that have been connected through human-mediated transportation of species. In some instances, invasion may be facilitated by the introduction of organisms in regions displaying environmental characteristics, including climate, soil, disturbances, similar to those of their native range, as highlighted by Hufbauer et al. (2012). In this vein, a non-native population would be "pre-adapted" to environmental conditions of the recipient ecosystem (2: PREAD) (Mack, 2003; Vermeij, 1991). For example, in marine environments, ocean sprawl, i.e., the worldwide artificialization of coastal marine habitats, is a major driver of invasion success (Bishop et al., 2017). This high prevalence of non-native organisms in artificial habitats, which are hubs and bridgehead for their future spread (3: BRIDG, bridgehead scenario/effect, Lombaert et al., 2010), may presumably result from adaptation to resist some particular abiotic factors typical of these habitats (such as pollutants, climatic conditions, availability of trophic resources), which evolved in their native range.

The continuing increase in the number of invasive populations worldwide (Seebens et al., 2017) is strongly related to anthropochory (4: ANTHRO) through interand intra-continental exchanges (Perrings et al., 2005). Populations are transported along commercial and touristic routes by aircraft, ships, cars or hikers. For example, invasion routes of the fruit fly Drosophila suzukii are closely related to fruit trade flows and pathways (Cini et al., 2014); the invasion of European countries by the horse chestnut leafminer Cameraria ohridella was supported by flows of people, cars, trains and trucks (Gilbert et al., 2004). The invasion of the Great Lakes drainage basin by numerous PontoCaspian species, such as Dreissena mussels, has been ascribed to ballast waters (Ricciardi \& MacIsaac, 2000). A model based on observational data also showed that both shipping intensity and habitat match are good predictors of the risk of marine invasion (Seebens et al., 2016).

Unbridled anthropochory can lead to the introduction of multiple populations (Fig. 1). This process increases propagule pressure and the probability of population establishment. The Propagule Pressure Hypothesis (5: PROP) (Simberloff, 2009), also known as "introduction effort" hypothesis (Blackburn \& Duncan, 2001), combines the number of propagules introduced and the number of introduction events. It is recognized as a major universal determinant of establishment and further colonization success of nonnatives. As such, this hypothesis is often seen as the "null model" when looking for determinants of species invasions (Colautti, Grigorovich \& MacIsaac, 2006; Cassey et al., 2018). Indeed, high propagule pressure increases the probability of persistence of the nonnative populations by counteracting negative effects associated with small populations (mostly Allee effects), and helps increase genetic diversity, and thus adaptive potential of non-native populations.

(2) First contacts of non-native organisms with their recipient ecosystems 
Non-native organisms can fail to integrate into the introduction area, partially succeed in integration, or become fully integrated and establish self-perpetuating populations. Williamson et al. (1996b) studied the proportion of imported species (including pests) achieving different levels of invasion success: 1 in 10 imported plants or animals subsequently appear in the wild (introduced or casual) into recipient communities. The same proportional rule prevails between introduced and naturalised populations, and between naturalised and invasive populations (6: 3TENS, the "3 tens rule"; Williamson, 1996a).

The causes of invasion failure are still poorly studied. In most cases, characteristics of individuals do not match with biotic and/or abiotic characteristics of the area of introduction (but see below 7: SINV, 8: EINV and 9: ELTON). In some instances, nonnative population characteristics and recipient environment characteristics may match only partially. In this case, the newcomer organisms face difficulties to fully ensure their fundamental biological functions. For instance, some non-native plants are unable to reproduce sexually in their invasion range (Lambertini et al., 2010). Their proliferation is almost exclusively or totally ensured by clonal multiplication (10: CLON), at least in the early stage of the invasion process. Their sterility can be due to sub-suitable climatic conditions in recipient ecosystems (e.g. too cold to allow reproduction), to pollen sterility or auto-incompatibility, to the absence of cross-fertilization (low number of partner or dioecious species with only one sex introduced in the invasion range (Lambertini et al., 2010), or to the absence of associated pollinators (Bufford \& Daehler, 2014). Importantly, this apparent weakness of the lack of sexual reproduction may be converted into an advantage when vegetative reproduction is more efficient than sexual one for invading recipient ecosystems (Lambertini et al., 2010). Such clonal reproduction is frequent among non-native ornamental populations (Bufford \& Daehler, 2014) and aquatic plants, and has been reported in both recent (Elodea nuttallii, Lagarosiphon major; Egeria densa) and ancient Vinca minor (Darcy \& Burkart, 2002; Čepková et al., 2016) plant invasions.

The successful integration of non-native organisms in the new area highly depends on their intrinsic characteristics, i.e. species invasiveness (7: SINV) (Pyšek \& Richardson, 2007; Richardson \& Pisek, 2006), and on the characteristics of the recipient environment, i.e. ecosystem invasibility (8: EINV) (Alpert, Bone \& Holzapfel, 2000; Richardson, 2006). Invasiveness and invasibility usefully tease apart the determinism of species invasions. These concepts avoid dressing one-sided considerations that would assign the "invasive" attribute to a species regardless of the characteristics of the invaded habitat, or conversely attribute the feature "invasible" to an ecosystem regardless of the traits of potentially invasive organisms (Sol, Vilà \& Kühn, 2008). A more synthetic view integrates the relationship between SINV and EINV. For instance, the framework proposed by Hui et al. (2016) considers the invasion fitness of an introduced population as a function of its trait value relative to the trait values of resident populations, or relative to the degree of trait saturation in the recipient community. Similarly, David et al. (2017) highlighted that the phylogenetic, functional, or ecological originality of an invading population relative to the recipient community can also affect the likelihood of its establishment success.

(3) Key determinants of species invasiveness 
Species invasiveness (7: SINV) resides in (i) the performance, (ii) the originality and (iii) the plasticity of functional traits. Yet, the ability to predict which introduced populations will become invasive remains fuzzy (Mack et al., 2000; Williamson, 2006; Romanuk et al., 2009). Several authors have tried to resolve this question by asking whether invasive populations share biological traits and, in parallel, whether invaded habitats have similar features to ascertain which ones could be associated to ecosystem invasiveness (8: EINV) (Lonsdale, 1999; Kolar \& Lodge, 2001; Romanuk et al., 2017).

The functional traits that enable a non-native population to become a successful invader (7: SINV) are usually those that favour fast reproduction and dispersal to rapidly establish viable populations. Those traits are, for plants, high ploidy level and uniparental reproduction, and for plants and animals, high reproduction rate, high phenotypic plasticity, broad and flexible diet, reduced systemic inflammatory responses (Lee \& Klasing, 2004), and a broad ecological tolerance that allow establishment and subsequent potential spread (Rejmanek \& Richardson, 1996; Alpert, Bone, \& Holzapfel, 2000; Kolar \& Lodge, 2001; Pyšek \& Richardson, 2007). The meta-analysis of van Kleunen et al. (2010) established that invasive plant species generally have higher values of performancerelated traits (11: HTRAIT) characterizing physiology, leaf-area allocation, shoot allocation, growth rate, size, i.e. better values for many proxies of plant fitness, than noninvasive species do. However, several contradictory results of global analyses searching for important traits have been reported (Daehler, 2003; Leffler et al., 2014). For Kueffer et al. (2013), conclusions about the invasiveness and impacts of a non-native species can be misleading without an understanding of the anthropogenic, ecological and evolutionary processes.

The Life History hypothesis (described as "Ideal Weed" in plant ecology) is directly related to the invasiveness concept and focuses on traits of non-native plant populations enhancing their establishment, spread and/or competitive abilities allowing to outcompete indigenous populations (Elton, 1958). Among these traits, in light of Baker's law (Baker, 1967), uniparental reproduction through, for instance, autonomous selfing or asexual reproduction is likely to be part of the invasiveness syndrome. Indeed, uniparental reproduction has consistently been reported in invasive terrestrial plants, across biogeographic regions and taxa (van Kleunen \& Johnson, 2007; van Kleunen et al., 2008), as an important trait for both establishment and spread (Pannell et al., 2015). However, theoretical models on the evolution of dispersal and selfing in plants indicate that selfing in invasive species could only be expected under certain circumstances, not in general (Cheptou \& Massol, 2009; Massol \& Cheptou, 2011a, 2011b).

Compared with their native congeners, many non-native individuals possess original, species-unique traits, which can contribute to their invasion potential (12: TRAIT), i.e. no functionally equivalent trait is present among the species of the invaded ecosystem (Atallah et al., 2014; Macel et al., 2014). Individuals with novel life form arriving in a new environment have good chances to become invasive (Mack, 2003). In particular, a limited functional redundancy with native organisms enhances establishment success (Ordonez, Wright, \& Olff, 2010; Divíšek et al., 2018). Accordingly, the concept of limiting 
similarity (14: SIMLIM; Abrams, 1983) states that invasive populations will be unlikely to establish in a community dominated by functionally similar populations because of greater niche overlap (MacArthur \& Levins, 1967; Funk et al., 2008). Numerous studies have investigated the role of limiting similarity in invasion success, sometimes supporting (e.g. Dukes, 2001; 2002; Wang et al., 2013), sometimes contradicting (e.g. Larson et al., 2013; Yannelli et al., 2017) the SIMLIM theory. For example, Dukes (2002) found the summeractive annual invasive forb Centaurea solstitialis to be most effectively suppressed by the presence of Hemizonia congesta ssp. luzulifolia which belongs to the same functional group. Conversely, Larson et al. (2013) showed that invasion success of the thistle Cirsium arvense was not affected by the presence of confamilial species, while early establishment of dissimilar guilds had negative effects.

Adaptive phenotypic plasticity, which confers high performance in a broad range of environmental conditions (Richards et al., 2006), may also be key of establishment success, by allowing an invader to thrive in environmental conditions that only partially match those of its native area (see Renault et al., 2018 for a review). According to the phenotypic plasticity hypothesis (13: PLASTI), invasive organisms may have a greater plasticity in ecologically important traits as compared with non-invasive ones. In addition, populations of invasive species are expected to evolve greater plasticity in their invasive range compared to populations within the native range (Richards et al., 2006). The phenotypic plasticity hypothesis has supporting examples (e.g. Davidson, Jennions, \& Nicotra, 2011), but also counter-examples (e.g. Palacio-López \& Gianoli, 2011). Fewer studies compared invasive and non-invasive populations, and most of these investigations concern plants. For instance, Lamarque et al. (2015) compared populations of Acer negundo and Acer platanoides from both their invasive and native ranges. These authors found that invasive populations of $A$. negundo expressed greater plasticity for diameter growth and phenological sensitivity, while no differences were observed between populations of $A$. platanoides. According to (Lande, 2015) the discrepancy in the observed tendency can be explained by several parameters, including the type of plasticity (reversible vs. irreversible). Plasticity should theoretically be highly beneficial at the early stages of invasion, because of the probable costs of maintaining plasticity (van Kleunen \& Fischer, 2005), and because it may allow for novel genetic variation to arise (Pigliucci, Murren, \& Schlichting, 2006). A trait may then lose its environmental sensitivity, and therefore become stable to environmental changes by genetic assimilation (Pigliucci et al., 2006). However, fluctuating environments are predicted to favour phenotypic plasticity, and this could explain the long-term persistence of plasticity in invaders of disturbed areas. The maintenance of adaptive plasticity could also be based on particular molecular genetic mechanisms, such as environmentally sensitive alleles, regulatory loci or epigenetic variation inducing environment-dependent expression patterns (Bock et al., 2015; Estoup et al., 2016; Gutekunst et al., 2018).

Searching for lists of traits related to invasiveness, such as phenotypic plasticity or original traits, has often remained inconclusive (Mack et al., 2000). These traits are only applicable to a few taxonomic groups (Kolar \& Lodge, 2001) and are context-dependent 
(Leffler et al., 2014). This extensive work on traits has revealed the large variety of invasive strategies, which depends on the temporal interaction of habitat characteristics and individual traits (Fig. 1). Importantly, the determinism and role of traits of invasive organisms change with the stage of ecosystem transformation, and this has been poorly considered so far. In historical ecosystems, trait characteristics of the newcomer (performance, originality and plasticity) have been acquired/preselected in their native areas. At this initial stage of invasion, trait originality seems to be a particularly important requisite, as the new populations need to make use of original niche and resources. Furthermore, trait plasticity enables invaders to enter and occupy disturbed and environmentally varying habitats across the globe.

\section{(4) Biotic resistance as guardian of historical ecosystems}

Ecosystem invasibility (8: EINV) is determined by abiotic (physico-chemical factors) and biotic components (e.g., local community composition, ecological networks, competition, predation). The biotic resistance of the recipient ecosystem partly explains the failure of many invasion attempts, previously described by the 3 tens rule (6:3TENS). Some historic ecosystems are species-rich, stable and may hinder the infiltration and integration of new populations. Since Elton's hypothesis (9: ELTON), we know that species richness in a community partly explains its resistance to the arrival and integration of new populations, including non-native populations (Elton, 1958; Levine \& D'Antonio, 1999). In theory, at least two different mechanisms can explain this pattern: either resource and niche availability decrease with species richness, or species-rich communities tend to comprise competitively superior species (Stachowicz \& Tilman, 2005). Most experimental tests to date seem to favour the former interpretation, i.e. that species-rich communities are protected against invasion through a saturation of niches and a decrease in resource (Tilman, 1997; Stachowicz \& Tilman, 2005; but see Hodgson, Rainey \& Buckling, 2002 for an experimental counter-example involving species dominance in bacterial communities). Such a biotic resistance hypothesis assumes that the number of filled niches should be greater in a species-rich assemblage, which would also include a greater number of predators and competitors (Crawley et al., 1999). Both native plant species richness and functional group identity are important mediators of opportunities for the establishment success of an invasive population, as shown for the waterweed Lagarosiphon major (Petruzzella et al., 2018). The number of non-native populations in an ecosystem accumulates over time, and may also modify (increase or decrease) the biotic resistance of historical ecosystem. Previous invasions can increase invasion resistance for functionally similar invaders by removing the populations more sensitive to invasion (Rodriguez, 2001). Conversely, ingress of a non-native population may also open the door for further invasive ones, as suggested by the invasional meltdown hypothesis (49: MELT) which is discussed below. Stohlgren et al. (1999) showed that hot spots of plant diversity and biodiversity in general were successfully invaded by non-native plant populations in many landscapes in the USA, with a probable link with the degree of resource availability in native plant communities, independently of species richness. It was thus suggested that high species richness may not systematically support a complete use of all available 
resources, community stability, or resistance to invasion; conversely negative richnessinvasibility correlations might not always be due to ecological processes but might instead be attributed to sampling effects (Wardle, 2001). Levine, Adler \& Yelenik. (2004) also suggested that biotic resistance may have a stronger influence on the non-native populations, once established, than during their establishment (Levine et al., 2004), as exampled by invaded native fish communities in the USA (Carey \& Wahl, 2010). Similarly, microcosm experiments by Dukes (2001) suggested that functional diversity is a better proxy of resistance against invasion, whereas species diversity is a good proxy of resistance against negative effects of the invader on the ecosystem, once established (Dukes, 2001).

Among the most important contributors of biotic resistance to invasions are the local native consumers / predators. Native consumers could prefer non-native over native prey, and may consequently limit invasions (Parker \& Hay, 2005). The mechanism behind this susceptibility of non-native prey to native consumers may be the absence of shared evolutionary history. The increased susceptibility hypothesis (15: ISH; Colautti et al., 2004) posits that non-native prey have not experienced selection from these consumers and therefore lack effective defences.

Several theoretical studies have assessed species invasiveness and ecosystem invasibility from a food web perspective, mostly by using the niche model of Williams \& Martinez (Williams \& Martinez, 2000). Such work suggests that low-trophic level generalists are better invaders than specialists or higher-level consumers (Romanuk et al., 2009). Conversely, more densely connected food webs are more resistant to invasions (meeting Elton's hypothesis, but through the number of links rather than the number of species), but suffer larger extinction cascades when a successful non-native population invades (Romanuk et al., 2017). Food webs with more compartmentalization (where food webs are subdivided into groups of species that are more likely to interact with one another than with those outside the compartment) were also less susceptible to invasion (Krause et al., 2003). Finally, the theoretical study of Hui et al. (2016), based on the evolutionary food web model of Loeuille \& Loreau (2005), indicates that the invasibility of recipient communities depends not only on their food web architecture, but also on the ecological characteristics and properties of the invading individuals.

\section{(5) Invasibility of habitats and ecosystems}

Many historical ecosystems show weaknesses and breaches ('invasion windows" sensu Johnstone, 1986) that are exploited by non-native populations at their establishment. The high invasibility of historic ecosystems, developed below, are mainly related to the use of niches neither exploited by local competitors nor defended by local enemies, such niches being more likely to occur in disturbed and heterogeneous sites.

In colonized habitats, non-native populations can potentially escape predators, pathogens, and parasites, which can be grouped under the general term "enemies" (Enemy 
Release Hypothesis, 16: ERH; Keane \& Crawley, 2002). This hypothesis predicts that a newly introduced invader establishes because of the lack of regulation by natural competitors and enemies (Williamson \& Fitter, 1996; Keane \& Crawley, 2002). For instance, using 26 host species of molluscs, crustaceans, fishes, birds, mammals, amphibians and reptiles, Torchin et al. (2003) found that introduced populations are less heavily parasitized than native ones. The absence of control by native enemies can in turn be partly explained by the Behavioural Constraint Hypothesis (17: $\mathbf{B C H})$. $\mathbf{B C H}$ establishes that potential consumers and competitors need behavioural adaptations before recognizing and readily consuming or outcompeting an introduced population under natural conditions (Lankau, Rogers \& Siemann, 2004). The absence of native "ecosystem guards" capable of slowing the progression of non-native population may increase the establishment success and geographic expansion in the invaded area.

According to the Empty Niche Hypothesis (18: ENH; Stachowicz \& Tilman, 2005), unsaturated ecological niches are poorly occupied because of their short evolutionary history (e.g., recent volcanic islands), their climatic (glaciation-deglaciation in northern systems), geologic and topographic (isolation of mountain ecosystems) histories, or their degree of anthropogenic alteration. The establishment success of non-native populations relies on the assumption of niche differentiation with native populations, involving either the exploitation of unused resources (empty niche), or enhanced competitive ability to access a shared resource (niche replacement). The functioning of the less interactive populations within these types of communities has also been described by the neutral theory (25: NEUTR; Hubbell, 2001; Chave, 2004). This theory has been applied to invasions with contrasted successes (Fargione et al., 2003; Herben et al., 2004; Tilman, 2004), even though it represents an opportunity (26: OPPO) that may ease the integration of non-native populations (Chabrerie et al., 2008).

The combination of the use of an empty niche and enemy-release opportunities (18: ENH and 16: ERH) is likely to facilitate the establishment of non-native populations (Shea \& Chesson, 2002). Both ENH and ERH invoke aspects of Charles Elton's hypothesis in seeking to explain the low biotic resistance of ecosystems. In this respect, insular ecosystems are particularly sensitive to the effects of invasion because they are often 'ecologically unsaturated', as depicted by the high number of non-native populations generally recorded on islands (Patiño et al., 2017). The high level of endemicity of island communities, which, in several instances, evolved under lower biotic pressures and in relative isolation as compared with continental communities, can make them more easily invaded by non-native populations. A famous example is the brown tree snake Boiga irregularis which decimated the avian forest community on Guam which was naïve to tree climbing predators (Wiles et al., 2003). A plant example is the invasion of the non-native tree Casuarina equisetifolia on recent volcanic flows on La Reunion Island (Potgieter et al. 2014). Other examples are the ability of the invasive fruit fly Drosophila suzukii to use unripe and ripening fruits before the other drosophila feeding on ripe and rotting fruits (Poyet et al., 2014), or invasive seed wasps who have priority access to limited resources due to earlier phenology than their competitors (Gidoin, Roques \& Boivin, 2015). Such 
cases point to invasive populations accessing unused or under-utilized resources or to gain competitive advantage to exploit shared and limited resources, leading to significant community-level impacts.

\section{(6) Environmental heterogeneity and habitat disturbance favour invasibility}

The environments in which invasions proceed are generally spatially and/or temporally heterogeneous in both their biotic and abiotic components. Environmental heterogeneity is likely to favour invasibility (19: HETE), possibly promoting coexistence mechanisms between native and non-native populations and limiting the ecological impact of invaders (Melbourne et al., 2007). For instance, pulsed resources generate episodes of increased resource availability that can both increase niche opportunities and relax interspecific competition; this can favour the establishment of non-native populations and the ability of native population to persist in the presence of competitive invaders (Davis, Grime \& Thomson, 2000; Shea \& Chesson, 2002). The environmental heterogeneity hypothesis also encompasses the Fluctuating Resource Hypothesis raised by Davis et al. (2000). This hypothesis assumes that invasion success can be favoured if (i) some resources are not (much) used (unsaturated niche, low to absence of functional redundancy), or (ii) if there is a temporal or spatial increase in resource availability for an opportunistic invader (Thiébaut, 2005), either through increase of supply (eutrophication), or (iii) resource use decreases through, for example, the local extinction of a competitor (Sher \& Hyatt, 1999; Davis et al., 2000). In many cases, this biotic and abiotic heterogeneity, which increases habitat invasibility, result from human-mediated disturbances.

Habitat disturbance (20: DIST) is globally recognized as an important feature of susceptibility to the installation and spread of non-native populations (Lozon \& MacIsaac, 1997). Many easily invaded environments correspond to disturbed ones, especially on oceanic islands (D'Antonio \& Dudley, 1995). Invasion frequency generally increases as levels of disturbance or ecosystem modification increases (Lonsdale, 1999; Richardson \& Pysek, 2006), as habitat disturbances affects native population abundance and diversity, in turn favouring non-native populations (Didham et al., 2005). MacDougall \& Turkington (2005) were among the first to empirically test the effects of habitat disturbance and invasive population abundance on native species declines using invasive grasses in firesuppressed oak savanna of British Columbia. Other example includes the intensive grazing which exacerbated the dominance of the invasive annual grass Bromus tectorum in the endangered Artemisia tridentata big sagebrush ecosystems of the Intermountain West, USA, by disrupting key resistance mechanisms associated with bunchgrass abundance and composition (Reisner et al., 2013).

\section{(7) Life history strategies of the colonizers along an invasion course}

The constellation of human-modified sites provides an intercontinental network of disturbed niches that facilitates the installation of r-strategy non-native populations (21: RSTR). These r-strategist populations/species are likely to be replaced by more 
competitive populations/species in later stages of the invasion (Facon et al., 2008). From this observation, two types of invasions can be distinguished: (i) early or "primary" invasions involving the appropriation of empty or poorly exploited niches and (ii) "secondary" invasions corresponding to the annexation of already occupied niches, possibly leading to competitive exclusion of taxa already present in those niches. Obviously, these two types of invasion are not expected to be associated with the same life-history strategies (Facon et al., 2006). Primary invasions will more frequently be caused by r-strategist species (Davis, 2005) with a set of life-history traits that facilitate colonization e.g., small size, early reproduction, high fecundity, short-life expectancy. A good illustration has been highlighted by Rejmánek \& Richardson (1996) who showed that pine species that invade habitats undergoing strong disturbances were mainly characterized by three r-selected traits, i.e., short juvenile period, light seeds, and short time intervals between breeding events.

On the contrary, secondary invasions will stem from K-strategist species with a set of life-history traits associated with competitive abilities, e.g., large size, late reproduction, low fecundity, long-life expectancy (22: KSTR). Two series of successive invasions, one concerning Tephritid flies in La Réunion island (Duyck et al., 2007) and the other on Thiarid snails in Martinique island (Facon et al., 2008), illustrate this process. In both situations serial replacements of taxa already present by better competitors occured in the same habitat. The key traits determining invasion success can be expected to shift during the course of an invasion (Sakai et al., 2001). Specifically, features related to r-strategies will be advantageous in the initial phases of invasion that mostly occur in historical ecosystems. Traits related to K-strategies will be favored in the subsequent stages of the invasion, when the invader enters into competitive interaction with the already invaded community in hybrid and novel ecosystems. A meta-analysis in birds suggested that invasiveness cannot be solely explained by the r-K trade-off (Sol et al., 2012). A bethedging life history, characterized by delayed reproduction and longer lifespan, could be the best invasive strategy reducing (i) the risk of reproductive failure associated with maladaptation to a novel environment and (ii) population fluctuations (Sol et al., 2012). It has been supported experimentally in an invasive ladybird by Tayeh et al. (2015), who highlighted that life histories can evolve rapidly within non-native populations, converging to a fine-tuned evolutionary match between the invader and the invaded environment.

\section{(8) Low effects of non-native populations on native diversity in the early stages of introduction}

At the onset of the invasion process, when the non-native population has been recently introduced into a historical ecosystem, its impact on community composition and ecosystem processes is usually superficial or even undetectable. This "ecological silence" accompanying the first stages of an invasion (latency period after introduction; 1: LATE) could explain why the reality of the consequences of invasive species on their host environment was initially hotly debated (Gurevitch \& Padilla, 2004; Asner et al., 2008; 
Simberloff et al., 2013). In the 1990s and early 2000s, a few studies demonstrated the effective impact of non-native plants on the diversity (especially species richness) of native plant communities (Costello, Lunt, \& Williams, 2000). The relationship between the richness of non-native species and that of native species could even be positive according to the spatial scale of observation (Sax, 2002; Byers \& Noonburg, 2003) and the nature of the interactions between the native and the non-native species. For example, the presence of the invasive Water Primrose can have a positive effect on local diversity and ecosystem processes since the plant may act as a 'magnet' species facilitating pollinator visits to the native species Lythrum salicaria (Stiers, Coussement, \& Triest, 2014).

Native and non-native species diversity are often positively correlated in largescale studies, but negatively correlated in small-scale studies (Sax, 2002; Byers \& Noonburg, 2003). Indeed, the same factors (light, degree of human-mediated modification of habitats, etc.) can have a positive effect on both non-native and native species, generating correlations between the diversity of the two groups of species, without the existence of strong causal relationships between native and non-native species diversity. The simple correlation between dominance of non-native populations and decline of native diversity does not constitute evidence that diversity changes are driven by nonnative populations (Didham et al., 2005).

\section{Expansion of non-native populations and modifications of assembly rules in hybrid ecosystems}

The main events characterizing the post-establishment stage of non-native populations are (i) their expansion, with a progressive adaptation to the environments encountered in their invasion area, and (ii) the modifications of assembly rules in hybrid ecosystems.

\section{(1) Paradoxical success of genetically impoverished populations}

Invasive populations are generally thought to be founded locally by a small number of individuals (Dlugosch \& Parker 2008) representing a more or less reduced fraction of the genetic diversity of the source population (Nei et al., 1975; Barrett \& Husband, 1990). This population/genetic bottleneck leads to high inbreeding levels (27: INBRE) in introduced populations (Willi, van Buskirk, \& Hoffmann, 2006). Furthermore genetic diversity is considered an important basis for the ability of populations to adapt to new environmental conditions (Fisher, 1930). From these two assumptions emerges the Genetic Paradox of Invasions (28: GPI): how do invasive populations adapt to the novel selective pressures encountered in the introduced area despite presumed reduced genetic diversity (Sax \& Brown, 2000; Estoup et al., 2016)? In this context, genetic analyses investigations first focused on comparing levels of genetic diversity between native and introduced populations (Bossdorf et al., 2005; Dlugosch \& Parker, 2008; Wares et al., 2005). Many authors showed decreased levels of genetic diversity in the introduced populations compared with the native populations (Hagenblad et al., 2015). However, reduced genetic diversity is not the rule in every environment. In particular, twenty years of genetic 
studies of introduced marine and aquatic populations have consistently reported similar or higher genetic diversity in introduced populations compared to their native counterparts (e.g., 76\% of the European marine introduced species, Rius et al., 2015). High propagule pressure from genetically diversified sources (5: PROP) can explain this pattern (Rius et al., 2015, Viard et al., 2016). Dlugosh et al. (2015) suggested that there is little explanatory power of the level of measured (and often neutral) genetic diversity on the introduction success. This does not imply that genetic variation is not important to consider, because 1) admixture processes may create evolutionary novelties, and 2) neutral genetic diversity may not correspond to adaptive variations on traits that are relevant for invasiveness (Rius \& Darling, 2014; Dlugosh et al. 2015; Viard et al., 2016).

Genetic bottlenecks do not seem to constrain invasive success (Sax et al., 2007), or even prevent rapid adaptive change (Prentis et al., 2008), as illustrated with the invasion case of Drosophila subobscura in Chile (Huey et al., 2005). Severe genetic bottlenecks have been demonstrated for introduced populations worldwide. This is, for example, the case of the seaweed Sargassum muticum, for which 14 microsatellites failed to detect any genetic variation over $>1200$ individuals sampled from 46 locations over its Pacific and Atlantic introduction ranges (Le Cam et al., 2019). In the same study, distinct introductions, but all accompanied by a severe genetic bottleneck, were then confirmed with ddRadSequencing. As pointed by Prentis et al. (2008), it is noteworthy that genetic bottlenecks can enable rapid adaptive change to occur (through the conversion of epistatic variance to additive variance for example (Whitlock et al., 1995) or a complex interaction between inbreeding depression and recipient environment (Schrieber \& Lachmuth, 2017). Alternative mechanisms such as phenotypic plasticity (13: PLASTI) could play a major role in the rapid adaptation of invasive populations as suggested for the parthenogenetic marbled crayfish (Gutekunst et al., 2018).

The genetic (and ecological) paradox between inbreeding depression and adaptive success of non-native populations may also be solved by understanding the evolution of the mutation load during the invasion process. The mutation load is defined as the proportion by which the population fitness, or any other attribute of interest, is altered by recurrent mutation (Kimura, Maruyama \& Crowe, 1963), and which constitutes a genetic burden. Consanguineous mating can purge a part of the mutation load and lethal mutations can also be purged in small populations (Glémin, 2003). Thus, small populations of non-natives, through the increase of consanguineous mating, may benefit from this purge of homozygous deleterious alleles (29: PURG) reducing their mutation load and promoting invasion, as it has been shown for the invasive harlequin ladybird (Facon et al., 2011).

\section{(2) Evolution of traits in non-native populations}

At early invasion stages, traits (variations in morphological, reproductive, life-cycle, physiological or chemical attributes) of individuals of non-native populations frequently differ from those of their congeners from the native range. Because they escape natural 
enemies in their invasive range (16: ERH), non-native populations can save the energy formerly used for defence, and reinvest it in growth, biomass, reproduction and competitiveness. This theory (Evolution of Increased Competition Ability, 30: EICA) first studied in plants (Blossey \& Nötzold, 1995) -and modified by Joshi \& Vrieling (2005)- may partly explain the classic phenomena of latency during naturalisation (23: LATE), and the sudden explosion of invasive populations after environmental filtering during the expansion stage (Pyšek \& Prach, 1993). This could also explain and reinforce the differences in performance commonly observed between native and non-native populations (Heberling \& Fridley, 2013), or between different populations of non-native species differing by the time since their introduction (Boiché et al., 2011). For example, Siemann \& Rogers (2001) demonstrated significant post-invasion genetic differences in the invasive tree species Triadica sebifera. Previously, Daehler \& Strong (1997) showed a reduction of herbivore resistance in introduced Spartina alterniflora after one century. Through this increase in individual performances of non-natives, fundamental ecosystem processes, such as productivity, would be gradually ameliorated in space, but also in time through the extended phenology of leaf production among non-native populations (Fridley, 2012). The EICA hypothesis was also modified by taking into consideration the defence of invaders against novel enemies, such as pathogens, encountered in their new habitats (Müller-Schärer, Schaffner, \& Steinger, 2004; Lee \& Klasing, 2004). However, studies attempting to test the EICA or refined EICA (more efficient and less costly immune responses) hypotheses have reported mixed results (Zou, Rogers \& Siemann, 2008; Cripps et al., 2009; Diagne et al., 2017).

\section{(3) Unbridled dispersal at the invasion front}

After a latency period (23: LATE) during naturalisation and release from natural enemies (16: ERH), non-native populations can expand rapidly their geographic range. In this process, dispersal ability crucially determines the speed at which colonisation of new habitats will occur (Renault et al., 2018). Range expansion is often characterized by sequential founder events (Slatkin \& Excoffier, 2012), resulting from short (stepping stone) or long-distance jumps. Individuals colonizing new habitats distant from the core population can have direct fitness advantages. Indeed, recently established individuals can benefit from decreased intra-specific competition pressure (Travis \& Dytham, 2002; Burton et al., 2010). Moreover, founder individuals, supposedly characterized by a majority of individuals with good dispersal abilities (Renault et al., 2018), will share and transmit their genetic background at the invasion front (passive assortative mating). As this phenomenon repeats as the invasion front moves forward, dispersal traits should be enhanced at the leading edge of the range expansion, generating phenotypic differentiation between front and core individuals (Laparie et al., 2013; Messager \& Olden, 2019), and possibly breaking genetic covariation between dispersal and other traits encountered in native populations (Brown et al., 2015). Behind the front wave and in core populations, higher population densities should favour competitive abilities of individuals, rather than biological traits enhancing their dispersal capacities (Burton et al., 
2010). The promotion of dispersal traits at the invasion front has been highlighted in the cane toad Rhinella marina rapidly invading the north-east coast of Australia (Phillips et al., 2006; 2010), and this has led to the theory of spatial sorting (31: SORT; Shine et al., 2011). Using such experimental evolution in replicated microcosm landscapes with different animal and plant models, several studies dissected which factors may drive the evolution of increased dispersal during range expansion and how this evolutionary shift may impact the ecological dynamics of invasion (Szucs et al., 2017; Weiss-Lehman, Hufbauer \& Melbourne, 2017). All these studies end to the conclusion that at least five different processes may impact the evolution of the dynamics of range expansions: 1) novel selection pressures in the new habitat, 2) spatial sorting, 3) lower density at the expansion edge, 4) gene surfing, and 5) number and genetic background of the founders.

The consequences of range expansion for population dynamics and the potential of invasive species to encompass rapid range expansion and adaptation are now being extensively studied in theoretical and empirical works (Courant et al., 2019; Morris, Börger \& Crooks, 2019). Despite such advances, our understanding of the processes generating phenotypic or genotypic variation in dispersal ability along the invasion gradient remains incomplete, especially under non-equilibrium conditions like range expansion and invasion (but see Phillips \& Perkins 2019). Moreover, human-assisted dispersal events and multiple reintroductions impede our understanding of the actual expansion sequence. Spatial sorting should contribute to selecting dispersive phenotypes at the front (see Chuang \& Peterson, 2016 for a review), the magnitude of this process being downregulated by a range of life-history trade-offs that may either facilitate or constrain invasion success, with subsequent fitness consequences (i.e. constrained energetic outputs). While there are supporting evidence for this expectation (Schreiber \& Beckman, 2019), some authors also failed in seeing reproductive consequences in the best dispersers (Tabassum \& Leishman, 2018). This area of invasion science seems very promising. For example, genomic scanning methods provide the tools for discriminating evolutionary forces occurring on the genome (demographic events or genetic drift affect the whole genome, whereas selection acts on particular loci). However, in the context of range expansion, drift is expected to be strong in low-density invasion-front populations, allowing random alleles to arise from standing variation and reach high frequencies, thus displaying a positive selection-like signal (mutation surfing; Gralka et al., 2016; Travis et al., 2010). White et al. (2013) showed that this problem could be solved by sampling replicated invasion-front populations, as surfing produced by drift would result in independent allele 'selection' when adaptive trait promotion would affect the same loci.

In contrast with spatial sorting, which tends to accelerate invasion waves, the existence of an Allee effect (32: ALLEE) in invasive populations can dampen invasion speed. An Allee effect is characterized as positive density-dependence of population growth at low density. Many processes can cause Allee effects, e.g. mate finding, pollen limitation, or collective behaviours affecting organism fitness, and it is likely a general process among animal and plant taxa (and yet proper evidence of demographic Allee effect is rare (Gascoigne et al., 2009; Kramer et al., 2009). The link between Allee effects and invasion 
has been the subject of several studies (Taylor \& Hastings, 2005; Grayson \& Johnson, 2018). Allee effects may decrease the probability that an invader will get established; examples of this include the pinewood nematode Bursaphelenchus xylophilus and its vector the pine sawyer Monochamus alternatus (Yoshimura et al., 1999) and the mass-attacking spruce bark beetle Ips typographus which had not established in North America in 2001 despite nearly 300 interceptions by US port inspectors since 1985 (Haack, 2001). Regarding the invasions that finally succeeded, such as the non-native vine Vincetoxicum rossicum (Cappuccino, 2004) or the smooth cordgrass Spartina alterniflora (Davis et al., 2004), negative effects of low density may explain the lag time before invasion (23: LATE). Evidence that Allee effects may slow spatial expansion has been gathered for the house finch Carpodacus mexicanus (Veit \& Lewis, 1996) and for the gypsy moth Lymantria dispar (Tobin et al., 2009); however, the dispersal capacities of introduced organisms may counteract Allee effects by increasing the chances of finding a mate, as reported in the house mice experimentally introduced on an island (MacKay et al., 2019).

While a large class of models have found that the Allee effect can decrease invasion speed (Travis \& Dytham, 2002), even to the point of countering spatial sorting (Shaw \& Kokko, 2015; Shaw et al., 2018), others have raised the possibility of peculiar phenomena taking place during invasion. Such phenomena include patchy range expansion and the decoupling of persistence and spatial spread in predator-prey systems (Petrovskii et al., 2005) or fluctuating invasion speeds when Allee effect is combined with negative densitydependence at large densities (Sullivan et al., 2017). Recent innovative theoretical work on the dynamics of invasion waves has also shown that Allee effects might help maintain higher genetic diversity at invasion fronts (Roques et al., 2012), partly because decreased invasion speed lowers the intensity of genetic drift (INBRE) at the front.

\section{(4) Role shifting from non-native passenger to non-native driver of ecosystem changes}

Given enough time, established non-native populations are likely to change assembly rules in their recipient community. Dominant invaders, through their activities, start modifying the ecosystem properties that pre-existed their introduction. Invaded ecosystems are thus progressively becoming 'hybrid' ecosystems (Mascaro et al., 2013), with features intermediate between historical ecosystems comprising only native populations, and the ecosystems affected by non-native ones. The non-native populations go from the status of "passenger" (24: PASS; MacDougall \& Turkington, 2005) to the status of driver of environmental changes. In the driver model (33: DRIVE; MacDougall \& Turkington, 2005; Chabrerie et al., 2008; White et al., 2013), invasive populations affect local diversity by using ecosystem resources and space more effectively than native ones (Parker et al., 1999). The dominant invaders subordinate native populations, which are thus limited or excluded by competition (MacDougall \& Turkington, 2005). Because of the great transformations imposed to invaded ecosystems, these non-native species have been termed invasive engineers (34: ENGE; Cuddington \& Hastings, 2004), drawing on the concept of ecosystem engineers proposed by Jones, Lawton, \& Shachack (1994). Invasive engineers (or habitat modifiers, habitat formers or bio-constructors) are among the most 
ecologically influential forms of biological invaders. Such populations create, destroy or transform the invaded habitats, thereby affecting native organisms (Guy-Haim et al., 2017). They sometimes trigger abrupt, and persistent changes in the structure and functioning of ecosystems akin to catastrophic shifts and alternative stable states studied in models of ecosystem functioning. The review by Guy-Haim et al. (2017), which focused on marine and estuarine environments, showed a wide variety of significant effects either positive or negative when considering studies separately, while concluding a small negative impact in their meta-analysis. Some studies show that the impacts of invasive ecosystem engineers depend on their density, and that at low density their effects can be positive (e.g. on soil microorganisms; Straube et al., 2009).

(5) Expansion of non-native populations associated with novel biological weapons and defences

The "Novel Weapon Hypothesis" (35: NWH; Callaway \& Ridenour, 2004; Vilcinskas, 2015) was formulated as an alternative explanation for the success of invasive populations. NWH posits that invasive populations may be equipped with new weaponry not detected or little used in the native range. In plants, numerous field and laboratory experiments have established the potential allelopathic effect of non-native populations on seed germination and direct inhibition of native plants (Thorpe et al., 2009; Pinzone et al., 2018). NWH also covers various invasive plant phytochemical activities, including antiherbivore functions, as well as anti-fungal and anti-microbial effects (Schaffner et al., 2011; Cipollini, Rigsby \& Barto, 2012). This has been demonstrated with the phytotoxic disruption of Alliaria petiolata on native mutualistic mycorrhizal associations (PortalesReyes et al., 2015). However, NWH is compatible with the biotic resistance hypothesis (9: ELTON) insofar as invasive populations 'weapons' can sometimes be thwarted by defence mechanisms in native species (Barto, Friese \& Cipollini, 2010), thus slowing their transformation into hybrid ones. The NWH can be (i) the result of changes of biological characteristics in the invasive population between its populations of origin and its host range or (ii) existing traits related to negative interactions with its natural enemies in its native range against which native population of its invasive range are not adapted (Callaway \& Ridenour, 2004; Yuan et al., 2013). In native plants, novel weapons of invaders are known to induce two responses: either (i) non-tolerance to the harmful allelochemicals due to the so-called "naïveté" observed with any antagonistic interactions (Schaffner et al., 2011; Carthey \& Branks, 2012) or (ii) evolved tolerance to novel allelochemicals through natural selection (Callaway et al., 2005).

The shifting defence hypothesis (36: SDH) differentiates between defences based on their effectiveness against specialist and generalist herbivores. It postulates that invasive plants may evolve towards new levels of chemical defence compounds in the invaded area for lack of their specialist herbivores (16: ERH), but are now under attack by native generalist herbivores (Joshi \& Vrieling, 2005; Doorduin \& Vrieling, 2011). Hence plants shift towards less expensive qualitative defences (toxins) and fewer quantitative ones in the introduced range because digestibility compounds are costly to produce (Glawe et al., 2003). An example is the Eurasian native Senecio jacobaea which is an aggressive invader in North America, Australia, and New Zealand. The production of 
pyrrolizidine alkaloids was found to be higher in the invasive populations of S. jacobaea compared to native populations, which makes invasive populations better defended against the generalist herbivore Mamestra brassicae. Pyrrolizidine alkaloids and other toxic compounds levels were also found at higher concentrations in invasive individuals than in native individuals in a common garden experiment (Doorduin \& Vrieling, 2011). If the defence chemicals against generalists are less expensive than the defence chemicals against the specialists, such an evolutionary shift in defence strategy in invasive populations may result in a net gain of resources for the plant, at the benefit of growth and reproduction (Joshi \& Vrieling, 2005).

Although NWH and SDH were first developed from work on invasive plants, they are also relevant for invasive animals. Some invasive insects harbour new chemical weapons by using molecules naturally present in the local resources of invaded ecosystems. This is the case of the non-native fruit fly Drosophila suzukii which is able to feed and use the toxic compounds of native plants present in its invasive range (Poyet et al., 2015). This drosophila lays its eggs preferentially in a toxic substrate (containing atropine, a compound naturally present in the fruits of the native plant Atropa belladonna) in the presence of parasitoids (Poyet et al., 2017). Interestingly, the presence of atropine in the developmental medium confers a better resistance of Drosophila offspring against parasitoids, thus revealing the existence of a form of transgenerational medication in this species. This new weapon may result from a shifting defence mechanism as the toxic plants used by the invasive insects are present in their invaded area but absent in their native area.

In contrast to native populations, some introduced plants can benefit from improved mutualisms with soil microorganisms (especially symbiotic fungi), which will increase their performance (Enhanced Mutualism Hypothesis, 37: EMH; Marler, Zabinski \& Callaway, 1999; Reinhart \& Callaway, 2006). According to the EMH, mutualism may be relatively more beneficial in novel ranges because the invasive population has escaped from the negative effect of natural enemies that may attenuate the positive effect of mutualists (mainly bacteria and fungi). For example, neutral to negative impacts of soil biota were found for the populations of Triadiaca sebifera in their native range (China) whereas positive effects of soil biota were reported in a North American non-native range of the species. These positive effects were linked to the higher levels of arbuscular mycorrhizal fungi colonization and to the greater net benefits to the invader in North America than in China (Yuan et al., 2013). Importantly, one needs to assess individual interactions between microbial species and non-native macro-organisms to tease apart the importance of EMH from ERH. In contrast with the EMH, the Mutualism Disruption Hypothesis (38: MDH; Callaway et al., 2008) predicts that invasive populations can also suppress soil mutualists in introduced ranges more aggressively than mutualists in their native ranges.

(6) Non-native species are playing with their natural enemies during the expansion stage 
Despite the loss of their enemies (16: ERH), non-native populations may carry some of their parasites (12 to 50\%) during the invasion process (Médoc et al., 2017). Parasites may spread into new environment and infect local species, which is defined as 'spillover' (Daszak, Cunningham \& Hyatt, 2000; Power \& Mitchell, 2004). Non-natives may also catch and amplify a part of local parasites, then constituting reservoirs for parasite transmission and acting as hosts to ultimately release them into ecosystem, which is defined as 'spillback' (Kelly et al., 2009a). For example, the co-introduction of grey squirrels, Sciurus carolinensis, and the squirrel poxvirus from North America to the UK led to the pauperization of local red squirrel, S. vulgaris (Tompkins, White \& Boots, 2003). Spillback can also induce untargeted metabolomics declines in native populations. For instance, the non-native grass Avena fatua amplifies and releases local viruses that are shared with the native grass Elymus glaucus, and then induce a population decrease of the latter species (Borer et al., 2007). These two phenomena are not exclusive and some cases report spillback and spillover processes (38: SPILL) occur on the same species. Weinstein \& Lafferty (2015) relate that dog's nematodes in North America were found within local species (spillover) and conversely local nematodes from red wolf, Canis rufus, were found within domestic dogs, Canis lupus familiaris, and thus increase inoculum size by release through native hosts (spillback).

Spillover and spillback processes (38: SPILL) have an effect on host-parasite dynamics and thus on ecosystems dynamics (Kelly et al., 2009b; Lymbery et al., 2014; Amsellemen et al., 2017). Several parameters (climate, temperature, difference in virulence, accumulation capacity, connectivity of host, etc) could affect parasite prevalence over time and space via spillback and spillover (Clark et al., 2018). A parasite introduced in a new area under more favourable climatic conditions could lead to more generations per year and thus more infections of native populations. The virulence could also affect the intensity of spillback and spillover (Strauss, White \& Boots, 2012). In the case of spillover, we expect that invasive populations could be already adapted to the associated parasite (Strauss et al., 2012). On the other hand, local species are at best insensitive to parasites. Parasites may have different effects on their hosts, ranging from death to avirulence. They can modify the host behaviour and make it more likely to be predated. In some cases, all conditions seem to be in place for a spillback and/or spillover process but it was not observed (Folcher et al., 2011). For now, some studies have explored the relationship between the phylogenetic proximity and the probability to share parasites but no clear patterns have emerged (Clark et al., 2018; Strauss et al., 2012; Streicker et al., 2010).

In some cases, invaders may act as poor hosts for native parasites; in these circumstances, their density and risk of infection will decrease, a phenomenon referred to as the "dilution effect" (Kopp \& Jokela, 2007; Kelly et al., 2009a). For instance, after the introduction of the non-native round goby, Neogobius melanostromus, the population of a local parasite, Dilostomum sp., declined. Invasive populations acted as a decoy for parasites and thus positively affected native fish which were less infected (Gendron \& Marcogliese, 2017). These phenomena can be difficult to observe, because either they occur too quickly (Dunn \& Hatcher, 2015) or the origin of the parasite is unclear. Finally, spillback and spillover processes might be common and their effects on native populations may be absent or valuable (avirulence or symbiotic for example). In the 
future, new technologies, including next-generation sequencing, should be used to detect parasites and their origins (Mangla, Inderjit \& Callaway, 2008; Wells et al., 2015), and thus better detect the occurrence of spillback or spillover phenomenon. In parallel, modelling offers opportunities for elucidation of the effects of such processes on population dynamics and a better understanding of parasite assembly (Stauss et al., 2012; Clark et al., 2018), as exampled in a range of genera (Dunn \& Hatcher, 2015). In general, when invasive species modify the community of parasites in their new areas, these can all gather in an "enemy alliance" (Strauss et al., 2012) that affects the interactions between native and nonnative populations.

\section{(7) A delayed invasion but an invasion debt to be finally paid}

The impact of invasive populations on recipient ecosystem is not immediate (23: LATE). Once a non-native is introduced in the historical ecosystem, its effects on natives may be delayed by the local biotic resistance (9: ELTON), the preponderant investment of introduced populations in dispersal efficiency (31: SORT), and the pace of adaptation of the non-native to its new environment (29: PURG, 30: EICA). The time lag between the introduction and the invasion stages can be very long (23: LATE), up to several centuries for some plant species (Groves, 2006). The LATE phenomenon was first observed for some weed species that are characterized by a time lag of more than 50 years between naturalization and a significant increase of their population. Groves (1999) first call them "sleeper weeds" (Groves, 1999). The term "invasion debt" (40: DEBT) was then used as a general term to describe the time-delayed invasion of populations that are already present in a region (Seabloom et al., 2006; Essl et al., 2011). This invasion debt is problematic because a low invasion level (i.e. a low number of introduced individuals) at a given time does not ensure the maintenance of ecosystem integrity in the future, even if no new individuals are introduced, thus masking the potential invasibility of ecosystems (Essl, Mang \& Moser, 2012). However, the concept of invasion debt also provides a valuable metric that can be used to quantify the dimensions of future threats (Rouget et al., 2016). By separating the invasion into components corresponding to different stages in the invasion process (introduction, establishment, spread and impact debts), Rouget et al. (2016) worked with 45 non-invasive Acacia species from South-Africa, and calculated that four could become established (establishment debt). The spread debt over a 20-year period varied from 0 (species unlikely to extend any further) to $10,000 \mathrm{~km}^{2}$ for species with a large potential range. This corresponds to a current impact debt of 174 million US\$ per species, which could increase to 500 million in 20 years if left unmanaged. In Europe, Haeuser et al. (2018) estimated the invasion debt of ornamental plant species by considering climate change. Modelling the effect of climate and species characteristics on naturalisation risk together with climate projections allows the forecasting of future threats and the implementation of proactive management of non-native populations. Preventing new introduction or managing current invasive populations does not eliminate the invasion debt, since debt already incurred will have to be paid in the future even if new introductions cease. 


\section{(8) Climate change as a major driver of non-native populations expansion}

Climate change (39: CLIM) can alter the reproductive strategies of non-native plants, by promoting a shift from clonal spread to greater sexual reproduction as it was established for Reynoutria taxa in northern regions (Holm et al., 2018). Changing climatic conditions can also facilitate the reproduction and subsequent establishment of non-native populations that have until now not been able to establish. Such successful non-natives may in the future encounter conditions more suitable for breeding and spread, as exampled by the tree Schinus molle in South Africa (Richardson et al., 2010). Global changes may also facilitate the transport and arrival of new non-native populations (Gillard et al., 2017). The review of Juroszek \& von Tiedemann (2015) also established that disease risk is projected to remain unchanged or to be reduced in the future, mainly due to supraoptimal temperature conditions for the development of some pathogens during the growing season and/or reduced rainfall and leaf wetness, respectively. Climate change can exacerbate the impact of invasive populations on ecosystem through the disruption of the local species interaction networks. Specifically, warming alters plant-herbivore interactions by increasing ectotherm metabolism and growth rates (Miranda et al., 2017), potentially leading to phenological mismatches between plants and pollinators, predators and prey, and pests and hosts.

\section{Rapid evolution of non-native populations and emerging properties in novel ecosystems}

\section{(1) Admixture and hybridization of non-native populations}

Introduced populations may have been founded by different divergent lineages which were spatially isolated in the native species range. These introduced individuals with distinct genetic background may come into contact and reproduce; the result of this interbreeding between two or more previously isolated genetic lineages (in the native or in the introduced ranges) is called genetic admixture (41: ADMI). ADMI increases the overall genetic variance, generates heterozygosity and heterosis, and increases species fitness (Keller et al., 2014; Lawson Handley et al., 2011). ADMI can contribute to enhancing the spread and can facilitate the adaptation of introduced populations, as suggested for the green crab Carcinus maenas, following the independent introduction and hybridization between cold- and warm-adapted ecotypes (Jeffery et al., 2018 and references therein). The same process may, on the other hand, also contribute to outbreeding depression, i.e. a decrease in average fitness. The role of admixture in biological invasions remains an open question and deserves further work (Rius \& Darling, 2014).

In cases where populations were fully reproductively isolated, inter-specific hybridization and introgression (42: HYBRID) can occur, as shown in salamanders (Fitzpatrick et al., 2010), marine mussels (Saarman \& Pogson, 2015) or plants (Abbott, 1992; Petit et al., 2004). Hybridization might benefit the non-native populations through adaptive introgression (Hedrick, 2013) (i.e. the introgression of adaptive alleles from 
native to non-native populations), and also threaten native populations (Todesco et al., 2016). Using a modelling approach validated by data obtained in two Cakile species, Mesgaran et al. (2016) proposed that hybridization might also protect the non-native populations from genetic Allee effects. Importantly, hybridization can occur without introgression, as shown in bird species in the genus Himantopus (Steeves et al., 2010) and in the tunicate Ciona spp. (Bouchemousse et al., 2016). Both intra- and inter-specific hybridization (sensu lato) are important mechanisms to consider as they could, among other things, counteract genetic depletion of founder events, and finally promote evolutionary novelties by breaking species boundaries (Harrison \& Larson, 2014; Rius \& Darling, 2014). From a genomic standpoint, rearrangements (43: GENO), like chromosomal inversions (Prevosti et al., 1988) and polyploidization (44: POLY) have been reported in Spartina species where hybridization between native and non-native taxa produced offspring with a wide range of chromosome numbers and fertility levels (Ainouche et al., 2009). In this context, the resulting complex evolution form, named "reticulate evolution" (45: RETIC) (Trewick et al., 2004; Linder \& Reiseberg, 2004), can occur in species with relatively close common ancestors (species of the same or a closely related genus). At long terms, these complex forms of evolution may result in adaptive radiation (46: RADIA) of introduced populations confronted to contrasted environments in postinvasion events \{Carroll \& Dingle, 1996). Finally, the selection resulting in evolutionary adaptations may possibly lead to speciation (47: SPECIA) in invasive species (Lee, 2002); thus the invasive species of today would be the native species of tomorrow.

In some cases, after a period of successful proliferation and expansion, an invasion may peter out, ending its race in an ecological and/or evolutionary dead-end (48: DEAD). This final and long-term invasion failure is different from the 3 tens rules (6: 3TENS) which corresponds to a short-term introduction failure due to a mismatch between the requirements of non-native populations (invasiveness) and recipient habitat characteristics (invasibility). The reasons for eventual long-term invasion failures are still to be studied. The trait performance or genetic diversity of the invasive population may decrease with time.

\section{(2) New species, new rules, new properties, new ecosystems}

The accumulation of non-native populations in a territory over time (Seebens et al., 2017) inevitably leads to new interactions; these may be weak or strong, positive or negative (see 35: NWH and 36: EMH). In a few cases (10 of the 256 case studies reviewed in Simberloff \& Von Holle, 1999), the establishment of newly introduced populations is facilitated by previously introduced species. This is the concept of invasional meltdown (49: MELT; Simberloff \& Von Holle ,1999). This facilitation between former and recent invaders can be due to increased ecosystem invasibility, linked to reduced species diversity (9: ELTON), or by environment transformation by ancient invasive populations (34: ENGE). Through cascading effects, former invaders then increase the probability of survival of newly introduced ones as well as the potential magnitude of their impact on 
the ecosystems. This is the case of the American cherry tree, Prunus serotina, introduced to Europe near Paris in 1623 (Starfinger, 1997). This species hosts and feeds the larvae of the Asiatic spotted wing drosophila (Drosophila suzukii) in its fruits (Poyet et al., 2014), a fly detected in 2008 for the first time in Europe (Asplen et al., 2015). In the same geographic location, organisms from three regions (Europe, North America and Asia) have met (Poyet et al., 2014). From a theoretical viewpoint, invasional meltdowns have been modelled in food webs, following the classic niche model, to assess the effect of non-native species coexistence (before the 'impacting' stage of invasion) on final invasion success (Pantel et al., 2017): while coexistence of non-native populations is not necessary to obtain an increasing probability of invasion success with the number of species introductions, introductions of populations that have previously coexisted elsewhere increases the slope linking the number of introductions to the fraction of successful invasions and thus make invasional meltdown more intense (Pantel et al., 2017).

These recurrent international meetings of invasive populations over time produce novel combinations of non-native/native or non-native/non-native populations (50: COMBI) that are characterized by different biogeographic and evolutionary histories but complementary traits. Among these new combinations, new relationships between native and non-native populations can facilitate or impede the establishment of the non-native population (The New Associations Hypothesis NASS; Colautti et al., 2004). Local adaptation of species in the native community or native-invasive coevolution can diminish the impact of invaders and integrate them into the native communities (Strauss, Lau \& Carroll, 2006; Lankau, 2012). From these associations, new environmental conditions and new ecosystem functions may emerge while others disappear. A new ecosystem applied to invasions (Novel ecosystem concept: Hobbs et al., 2006; Mascaro et al., 2013; Richardson \& Gaertner, 2013; 51: NOVEL) is being created with emerging properties (Forsyth et al., 2015; Kuebbing, Classen, \& Simberloff, 2014) and with altered ecosystem services (Hobbs, Higgs \& Harris, 2009).

Novel ecosystems are characterized by the unprecedented nature of their structure and composition and often by the irreversibility of the invasion. Indeed, the return to a previous state of the ecosystem or the total eradication of an established invasive population is almost impossible in practice. Beyond their ecosystem impact, some invasive populations redefine the dynamics of landscapes and constrain management habits (Chabrerie et al., 2007). The multiplicity of potential combinations of species, previously unlikely and now possible, makes it difficult to predict what will be the ecosystem properties resulting from these association lotteries.

\section{A functional perspective of invasions and future directions}

The link between the various hypotheses and theories presented therein and the effects of invasive populations on invaded ecosystem services appears as a topic deserving further research. Whether a non-native population succeeds in a novel environment because it lacks its natural enemies (16: ERH) or because of too much disturbances of the invaded 
ecosystem (20: DIST) might provide clues as to what the effect of the non-native population might be on the functioning of invaded ecosystem and its services.

Understanding biological invasions demands consideration of complex interactions between intrinsic species attributes, environmental attributes, and the effects of human actions (Thuiller et al., 2006). However, this does not mean that it is not possible to forecast future trajectories of invasions (Bocedi et al., 2014; Fournier et al., 2019). We suggest that Fig. 1 can serve as a graphical model whose components can be used to construct more formal statistical models of population, community, or ecosystem dynamics in habitats where researchers are interested in predicting changes in response to non-native populations or the likelihood of particular habitats to host invasive species. The model parameters can be tuned using other examples of invasions in the same or similar taxonomic groups or habitat types, sources of uncertainty in the model can be assessed, and the models can be fine-tuned as more data becomes available in an iterative updating process (Dietze, 2017; Urban et al., 2016).

A functional approach to ecosystem, based on the use of organism traits, would provide a significant improvement of our understanding of ecosystem changes following invasions (Drenovsky et al., 2012; Liao et al., 2008). A functional approach can help assess whether ecosystem states pre- and post-invasions are functionally homologous, and whether the services provided by ecosystems have changed (e.g. carbon storage, water quality). Several studies comparing coexisting native and invasive plant species have demonstrated differences between them in terms of functionally important traits (Baruch \& Goldstein, 1999; Leishman et al., 2007). Invasive populations, bearing new effect traits, will alter the functioning of recipient ecosystem, but up to now only few studies have linked these alterations to the trait sets of non-natives (Levine et al., 2003). Through adaptive changes of morphological (Atallah et al., 2014) or behavioural traits, e.g. transgenerational medication (Poyet et al., 2017), non-native populations can benefit from a wider range of resources (Poyet et al., 2015) or better defend themselves than local populations and thus take precedence over them. However, native populations can also experience adaptive evolution in performance traits that mitigate the impact of nonnatives (Mealor \& Hild, 2007).

Considering the functional characteristics of invasive populations can also help assess, understand and predict their effects on ecosystem services. For instance, Geslin et al. (2017) reviewed the literature on the effects of widely introduced populations of crops and pollinating insects on plant-pollinator interactions. One of their main conclusions is that domesticated insects generally occupy central positions in networks, and therefore probably compete with many other naturally occurring pollinators. In the case of the regulation of agricultural pests by predators, Jacquot et al. (2017) investigated the potential services and disservices of invasive ants in mango orchards, and they evidenced that distinct ant species had different effects depending on their omnivory and the trophic level on which they preferentially feed. 
Finally, since parasites (sensu lato, i.e. pathogens and true parasites) are involved in indirect interactions at all trophic levels, parasitic infections play a major role in invasion impact and success. Host-parasite interactions control and are controlled by the host immune response, and yet the immunology of invasions is still poorly known, with a clear imbalance in favour of theoretical rather than empirical studies (but see Vilcinskas, Mukherjee \& Vogel, 2013). This observation is even more pronounced in invertebrate species, although it is now well established that invertebrates can acquire an immune experience from newly encountered microbes and transmit it to their offspring.

The overall message from this review and the synthetic timeline scheme (Fig. 1) is that invasions do not occur in a vacuum and no single hypothesis is adequate to predict the likelihood of invasion, the resilience of particular ecosystems to invasion, the alteration to expect after the invasion, or the likely evolutionary aftermath to result from the integration of the invasive species.

\section{Conclusions}

(1) Our review has fully explored and synthesised theories and hypotheses aimed at elucidating aspects of biological invasions at the level of populations, communities and ecosystems. We propose logical articulation and links between theories along an invasion timeline, from establishment to expansion and then evolution of invasive populations

(2) For the first time, our large-scale visualisation of the theories allows linking them, as for 7: SINV and 8: EINV hypotheses which both allude to the constraints on invasive population traits due to their insertion into local food webs, e.g. foraging traits matching available prey characteristics, in addition to highlighting potential redundancies as for 21: RSTR and 20: DIST theories which both emphasize the relation between the propensity of r-strategist species to be efficient invaders and the facilitation of such invasions by disturbances of ecosystems.

(3) We suggest that invasion theories can greatly benefit from a functional perspective. Using biological traits, allowing the computation of functional diversity indices at species and community scales, is a promising framework to understand changes in food webs and link ecosystem compartments such as below- and above-ground. Indeed, a better perspective of invaders' success could be achieved through elucidation of the actual roles of species, e.g. based on the consideration of the functional and ecological originality of the organisms, including species diet.

(4) We recommend that future studies consider developing a framework for integrating ecology, physiology, immunology and microbiology to better understand the key drivers of the different theories and steps along the invasion timeline picture in Fig. 1. The main challenges in this regard are measuring a pertinent set of traits for the different biotic components of the ecosystem and discerning links between measured traits and ecological functions or processes. 


\section{Acknowledgements}

The authors were supported by InEE-CNRS via a funded network dedicated to Biological Invasions (GdR CNRS 3647 Invasions Biologiques).

\section{References}

Аввотт, R.J. (1992). Plant invasions, interspecific hybridization and the evolution of new plant taxa. Trends in Ecology \& Evolution 7, 401-405.

Abrams, P. (1983). The theory of limiting similarity. Annual Review of Ecology and Systematics 14, 359-376.

Ainouche, M.L., Fornute, M.P., Salmon, A., PArisod, C., Grandbastien, M.-A., FukUnaGa, K., RICOU, M. \& MISSET, M.-T. (2009). Hybridization, polyploidy and invasion: lessons from Spartina (Poaceae). Biological Invasions 11, 1159-1173.

Alpert, P., BONe, E. \& Holzapfel, C. (2000). Invasiveness, invasibility and the role of environmental stress in the spread of non-native plants. Perspectives in Plant Ecology, Evolution and Systematics 3, 52-66.

Amsellem, L., Brouat, C., Duron, O., Porter, S. S., VilcinsKas, A. \& FACON, B. (2017). Chapter Three - Importance of Microorganisms to Macroorganisms Invasions: Is the Essential Invisible to the Eye? (The Little Prince, A. de Saint-Exupéry, 1943). In Advances in Ecological Research vol. 57 Networks of Invasion: Empirical Evidence and Case Studies (ed. D. A. Bohan, A. J. Dumbrell and F. Massol), pp. 99-146. Academic Press.

Asner, G.P., Hughes, R.F., Vitousek, P.M., KNAPP, D.E., KenNedY-BOWdOIN, T., BOARDMAN, J., MARTIN, R.E., EASTWOOD, M. \& GREEN, R.O. (2008). Invasive plants transform the threedimensional structure of rain forests. Proceedings of the National Academy of Sciences of the United States of America 105, 4519-4523.

Asplen, M.K., ANFOra, G., Biondi, A., CHOI, D.S., CHU, D., DAANE, K.M., GiBert, P., GutierreZ, A. P., Hoelmer, K.A., HutChISON, W.D., ISAACS, R., JiANG, Z.L., KÁRPÁTI, Z., KiMURA, M.T., PASCUAL, M., et al. (2015). Invasion biology of spotted wing Drosophila (Drosophila suzukii): a global perspective and future priorities. Journal of Pest Science 88, 469-494.

Atallah, J., Teixeira, L., SAlazAR, R., ZARAgOZA, G. \& Kopp, A. (2014). The making of a pest: the evolution of a fruit-penetrating ovipositor in Drosophila suzukii and related species. Proceedings. Biological Sciences 281, 20132840.

BAKER, H.G. (1967). Support for Baker's Law - as a Rule. Evolution 21, 853-856.

BARRETT, S.C. \& HUSBAND, B.C. (1990). Variation in outcrossing rates in Eichhornia paniculata: the role of demographic and reproductive factors. Plant Species Biology 5, 41-55.

BARTO, K., FRIESE, C. \& CIPOLLINI, D. (2010). Arbuscular mycorrhizal fungi protect a native plant from allelopathic effects of an invader. Journal of Chemical Ecology 36, 351-360.

BARUCH, Z. \& GOLDSTEIN, G. (1999). Leaf construction cost, nutrient concentration, and net CO2 assimilation of native and invasive species in Hawaii. Oecologia 121, 183-192. 
Bishop, M.J., MAYeR-PinTO, M., Airoldi, L., FirTH, L.B., MorRIS, R.L., LOKE, L.H.L., HAWKINS, S.J., NAYLOR, L.A., COLEMAN R.A., CHEE S.Y \& DAFFORN, K.A. (2017). Effects of ocean sprawl on ecological connectivity: impacts and solutions. Journal of Experimental Marine Biology and Ecology 492, 7-30.

BLACKBURN, T.M. \& DUNCAN, R.P. (2001). Determinants of establishment success in introduced birds. Nature 414, 195.

BlackBuRn, T.M., PYŠEK, P., BACHeR, S., CARlton, J.T., DunCAN, R.P., JAROŠIK, V., Wilson, J.R. \& RICHARDSON, D.M. (2011). A proposed unified framework for biological invasions. Trends in Ecology and Evolution 26, 333-339.

BlosseY, B. \& NÖTZOLD, R. (1995). Evolution of increased competitive ability in invasive non indigenous plants: a hypothesis. Journal of Ecology 83, 887-889.

Bocedi, G., PALmer, S.C.F., Pe'ER, G., HeikKINEN, R.K., MATSINOS, Y.G., WATtS, K. \& TRAVIS, J.M.J. (2014). RangeShifter: a platform for modelling spatial eco-evolutionary dynamics and species' responses to environmental changes. Methods in Ecology and Evolution 5, 388-396.

BoichÉ, A., Lemoine, D.G., Barrat-Segretain, M. H. \& ThiÉBAut, G. (2011). Resistance to herbivory of two populations of Elodea canadensis Michaux and Elodea nuttallii Planchon St. John. Plant ecology 212, 1723-1731.

Bock, D.G., Caseys, C., Cousens, R.D., Hahn, M.A., Heredia, S.M., HÜBner, S., Turner, K.G., WHITNEY, K.D. \& RIESEBERG, L.H. (2015). What we still don't know about invasion genetics. Molecular Ecology 24, 2277-2297.

Borer, E. T., Hosseini, P. R., Seabloom, E. W. \& DObSON, A. P. (2007). Pathogen-induced reversal of native dominance in a grassland community. Proceedings of the National Academy of Sciences 104, 5473-5478.

Bossdorf, O., Auge, H., Lafuma, L., Rogers, W. E., Siemann, E. \& Prati, D. (2005). Phenotypic and genetic differentiation between native and introduced plant populations. Oecologia 144, 1-11.

Bouchemousse, S., Liautard-HaAG, C., Bierne, N., \& Viard, F. (2016). Distinguishing contemporary hybridization from past introgression with postgenomic ancestry-informative SNPs in strongly differentiated Ciona species. Molecular Ecology 25, 5527-5542.

Brown, G.P., PhilliPS, B.L., Dubey, S. \& SHINE, R. (2015). Invader immunology: invasion history alters immune system function in cane toads (Rhinella marina) in tropical Australia. Ecology Letters $18,57-65$.

BUFFORD, J.L. \& DAEHLER, C.C. (2014). Sterility and lack of pollinator services explain reproductive failure in non-invasive ornamental plants. Diversity and Distribution 20, 975-985.

Burton, O.J., PhILLIPS, B.L. \& TRAvis, J.M.J. (2010). Trade-offs and the evolution of life-histories during range expansion. Ecology Letters 13, 1210-1220.

BYERS, J.E. \& NOONBURG, E.G. (2003). Scale dependent effects of biotic resistance to biological invasion. Ecology 84, 1428-1433.

Callaway, R.M., Cipollini, D., Barto, K., Thelen, G.C., Hallett, S.G., Prati, D., Stinson, K. \& KLIRONOMOS, J. (2008). Novel weapons: invasive plant suppresses fungal mutualists in America but not in its native Europe. Ecology 89, 1043-1055.

CALLAWAY, R.M. \& RIDENOUR, W.M. (2004). Novel weapons: invasive success and the evolution of increased competitive ability. Frontiers in Ecology and the Environment 2, 436-443. 
CALlaway, R.M., RidenOUR, W.M., LABOSKI, T., WeIR, T. \& ViVANCO, J.M. (2005). Natural selection for resistance to the allelopathic effects of invasive plants. Journal of Ecology 93, 576-583.

CAPinha, C., EssL, F., SEebens, H., Moser, D. \& Pereira, H.M. (2015). The dispersal of alien species redefines biogeography in the Anthropocene. Science 348, 1248-1251.

CAPPUCCINO, N. (2004). Allee effect in an invasive alien plant, pale swallow-wort Vincetoxicum rossicum (Asclepiadaceae). Oikos 106, 3-8.

CAREY, M. P. \& WAHL, D. H. (2010). Native fish diversity alters the effects of an invasive species on food webs. Ecology 91, 2965-2974.

CARroll, S.P. \& Dingle, H. (1996). The biology of post-invasion events. Biological Conservation 78, 207-214.

CARTHEY, A.J.R. \& BANKS, P.B. (2012). When does an alien become a native species? A vulnerable native mammal recognizes and responds to its long-term alien predator. PLoS One 7, e31804.

CAssey, P., Delean, S., LockWOOd, J. L., SADOWSKI, J. \& BlackBuRn, T. M. (2018). Dissecting the null model for biological invasions: A meta-analysis of the propagule pressure effect. Plos Biology 16, e2005987. doi:10.1371/journal.pbio.2005987

CATFORD, J.A., JANSSON, R. \& NILSSON, C. (2009). Reducing redundancy in invasion ecology by integrating hypotheses into a single theoretical framework. Diversity and Distributions 15, 22-40.

CATfORD, J. A., VeSK, P. A., RiChARDSON, D. M. \& PYŠEK, P. (2012). Quantifying levels of biological invasion: towards the objective classification of invaded and invasible ecosystems. Global Change Biology 18, 44-62.

ČEPKOVÁ, P.H., KARLíK, P., ViehMANNOVÁ, I., MÜllerovÁ, V., ŠMejDA, L. \& HejCMAN, M. (2016). Genetic and leaf-trait variability of Vinca minor at ancient and recent localities in Central Europe. Biochemical Systematics and Ecology 64, 22-30.

Chabrerie, O., Roulier, F., Hoeblich, H., Sebert-Cuvillier, E., Closset-Kopp, D., Leblanc, I., JAMINON, J. \& DECOCQ, G. (2007). Defining patch mosaic functional types to predict invasion patterns in a forest landscape. Ecological Applications 17, 464-481.

Chabrerie, O., Verheyen, K., SAGUeZ, R. \& DeCocQ, G. (2008). Disentangling relationships between habitat conditions, disturbance history, plant diversity and American Black cherry (Prunus serotina Ehrh.) invasion in a European temperate forest. Diversity and Distribution 14, 204-212.

CHAVE, J. (2004). Neutral theory and community ecology. Ecology Letters 7, 241-253.

CHePtou, P. \& MASSOL, F. (2009). Pollination fluctuations drive evolutionary syndromes linking dispersal and mating system. American Naturalist 174, 46-55.

CHUANG A. \& PETERSON C.R. (2016). Expanding population edges: theories, traits, and trade-offs. Global Change Biology 22, 494-512.

Cini, A., Anfora, G., Escudero-Colomar, L.A., Grassi, A., SAntosuosso, U., SeljaK, G. \& PAPINI, A. (2014). Tracking the invasion of the alien fruit pest Drosophila suzukii in Europe. Journal of Pest Sciences 87, 559-566.

CIPOLLINI, D., RIGSBY, C.-M. \& BARTO, E.-K. (2012). Microbes as targets and mediators of allelopathy in plants. Journal of Chemical Ecology 38, 714-727. 
Clark, N. J., ClegG, S. M., SAM, K., Goulding, W., KoAne, B. \& Wells, K. (2018). Climate, host phylogeny and the connectivity of host communities govern regional parasite assembly. Diversity and Distributions 24, 13-23.

Colautti, R., Grigorovich I. \& MacisaAC, H. (2006). Propagule pressure: A null model for biological invasions. Biological Invasions 8, 1023-1037.

COlAUtTI, R.I., Ricciardi, A., GRIGOROVICH, I.A. \& MACISAAC, H.J. (2004). Is invasion success explained by the enemy release hypothesis? Ecology Letters 7, 721-733.

COstello, D.A., LunT, I.D. \& Williams, J.E. (2000). Effects of invasion by the indigenous shrub Acacia sophorae on plant composition of coastal grasslands in south-eastern Australia. Biological and Conservation 96, 113-121.

Courant, J., SeCOndi, J., Guillemet, L., VOlLetTe, E., HerRel, A. (2019). Rapid changes in dispersal on a small spatial scale at the range edge of an expanding population. Evolutionary Ecology 33, 599612.

Crawley, M. J., Brown, S. L., HeArd, M. S. \& EDWARdS, G. R. (1999). Invasion-resistance in experimental grassland communities: species richness or species identity? Ecology Letters 2, 140148.

CRIPPS, M.G., HinZ, H.L., MCKenNey, J.L., PRICE, W.J. \& SCHWARZLÄNDER, M. (2009). No evidence for an 'evolution of increased competitive ability' for the invasive Lepidium draba. Basic and Applied Ecology 10, 103-112.

CUDDINGTON, K. \& HASTINGS, A. (2004). Invasive engineers. Ecological Modelling 178, 335-347.

D'ANTONIO, C.M. \& DUDLEY, T.L. (1995). Biological invasions as agents of change on islands versus mainlands. In Islands: Biological Diversity and Ecosystem Function (ed. P. M. Vitousek, L. L. Loope and H. Adsersen), pp. 103-121. Springer Berlin Heidelberg, Berlin, Heidelberg.

DAEHLER, C.C. (2003). Performance comparisons of co-occurring native and alien invasive plants: implications for conservation and restoration. Annual Review of Ecology, Evolution, and Systematics 34, 183-211.

DAEHLER, C.C. \& STRONG, D.R. (1997). Reduced herbivore resistance in introduced smooth cordgrass (Spartina alterniflora) after a century of herbivore-free growth. Oecologia 110, 99-108.

DARCY, A.J. \& BURKART, M.C. (2002). Allelopathic potential of Vinca minor, an invasive exotic plant in West Michigan forests. Bios 73, 127-132.

DASZAK, P., CUNNINGHAM, A.A. \& HYATT, A.D. (2000). Emerging Infectious Diseases of Wildlife-Threats to Biodiversity and Human Health. Science 287, 443-449.

David, P., Thebault, E., ANNeVIlle, O., DuYck, P.F., Chapuis, E. \& Loeuille, N. (2017). Impacts of invasive species on food webs: a review of empirical data. In Advances in Ecological Research vol. 56 - Networks of Invasion: A Synthesis of Concepts (ed. D. A. Bohan, A.J. Dumbrell and F. Massol), pp. 160. Academic Press.

DAVidson, A.M., Jennions, M. \& Nicotra, A.B. (2011). Do invasive species show higher phenotypic plasticity than native species and, if so, is it adaptive? A meta-analysis. Ecology Letters 14, 419-431.

DAVIS, H.G., TAYLOR, C.M., CiviLLE, J.C. \& STRONG, D.R. (2004). An Allee effect at the front of a plant invasion: Spartina in a Pacific estuary. Journal of Ecology 92, 321-327. 
DAVIS, H.G. (2005). r-Selected traits in an invasive population. Evolutionary Ecology 19, 255-274.

DAVIS, M.A., GRIME, J.P. \& THOMPSON, K. (2000). Fluctuating resources in plant communities: a general theory of invasibility. Journal of Ecology 88, 528-534.

Diagne, C., Gilot-Fromont, E., Cornet, S., Husse, L., Doucouré, S., Dalecky, A., BÂ, K., Kane, M., NiAnG, Y. \& DiAllo, M. (2017). Contemporary variations of immune responsiveness during range expansion of two invasive rodents in Senegal. Oikos 126, 435-446.

Dick, J.T., Alexander, M.E., Ricciardi, A., LAVERTy, C., DOWney, P.O., Xu, M., JeschKe, J.M., SAUl, W.-C., Hill, M.P., Wasserman, R., BARrios-O'Neil, D., WeYl, O.L.F. \& SHAW, R.H. (2017). Functional responses can unify invasion ecology. Biological Invasions, 19, 1667-1672.

DidHAM, R.K., TYliAnAKIS, J.M., HutChISON, M.A., EWERS, R.M. \& GEMMELL, N.J. (2005). Are invasive species the drivers of ecological changes? Trends in Ecology and Evolution 20, 470-474.

Dietze, M. C. (2017). Prediction in ecology: a first-principles framework. Ecological Applications 27, 2048-2060.

Diví̌̌eK, J., ChytrÝ, M., Beckage, B., Gotelli, N.J., LososovÁ, Z., PYŠEK, P., Richardson, D.M. \& MOLOFSKY, J. (2018). Similarity of introduced plant species to native ones facilitates naturalization, but differences enhance invasion success. Nature Communications 9, 4631.

Dlugosch, K. M., Anderson, S. R., BraAsch, J., CANG, F. A. \& GilletTe, H. D. (2015). The devil is in the details: genetic variation in introduced populations and its contributions to invasion. Molecular Ecology 24, 2095-2111.

DLUGOSCH, K.M. \& PARKER, I.M. (2008). Invading populations of an ornamental shrub show rapid life history evolution despite genetic bottlenecks. Ecology Letters 11, 701-709.

DOORDUIN, L.J. \& VRIELING, K. (2011). A review of the phytochemical support for the shifting defence hypothesis. Phytochemistry Review 10, 99-106.

Drenovsky, R. E., Grewell, B. J., D'Antonio, C. M., FunK, J. L., JAMES, J. J., Molinari, N., PARKer, I. M. \& RICHARDS, C. L. (2012). A functional trait perspective on plant invasion. Annals of Botany 110, 141-153.

DUKES, J.S. (2001). Biodiversity and invasibility in grassland microcosms. Oecologia 126, 563-568.

DUKES, J.S. (2002). Species composition and diversity affect grassland susceptibility and response to invasion. Ecological Applications 12, 602-617.

DunN, A. M. \& HATCHER, M. J. (2015). Parasites and biological invasions: parallels, interactions, and control. Trends in Parasitology 31, 189-199.

DUYCK, P.-F., DAVID, P. \& QUILICI, S. (2007). Can more K-selected species be better invaders? A case study of fruit flies in La Réunion. Diversity and Distribution 13, 535-543.

ELton, C.S. (1958). The Ecology of Invasions by Animals and Plants. University of Chicago Press.

ENDERS, M., HÜTT, M.T. \& JESCHKE, J.M. (2018). Drawing a map of invasion biology based on a network of hypotheses. Ecosphere 9, e02146.

Essl, F., Dullinger, S., Rabitsch, W., Hulme, P.E., Hülber, K., Jarošík, V., Kleinbauer, I., KRAUSMANN, F., KÜHN, I. \& NENTWIG, W. (2011). Socioeconomic legacy yields an invasion debt. Proceedings of the National Academy of Sciences 108, 203-207. 
ESSL, F., MANG, T. \& MOSER, D. (2012). Ancient and recent alien species in temperate forests: steady state and time lags. Biological Invasions 14, 1331-1342.

Estoup, A., Ravigne, V., Hufbauer, R., Vitalis, R., Gautier, M. \& Facon, B. (2016). Is there a genetic paradox of biological invasion? Annual Review of Ecology, Evolution, and Systematics 47, 5172.

FAcon, B., Genton, B.J., ShyKoff, J., JARne, P., Estoup, A. \& DAVid, P. (2006). A general ecoevolutionary framework for understanding bioinvasions. Trends in Ecology and Evolution 21, 130135.

Facon, B., Hufbauer, R.A., TAyeh, A., Loiseau, A., Lombaert, E., Vitalis, R., Guillemaud, T., LunDGREN, J.G. \& EsTOUP, A. (2011). Inbreeding depression is purged in the invasive insect Harmonia axyridis. Current Biology 21, 424-427.

FACON, B., JARne, P., POINTIER, J. \& DAvid, P. (2005). Hybridization and invasiveness in the freshwater snail Melanoides tuberculata: hybrid vigour is more important than increase in genetic variance. Journal of Evolutionary Biology 18, 524-535.

FACon, B., Pointier, J.-P., JARne, P., SARDA, V. \& DAVID, P. (2008). High genetic variance in lifehistory strategies within invasive populations by way of multiple introductions. Current Biology 18, 363-367.

FARGiONE, J., BROWN, C.S. \& TILMAN, D. (2003). Community assembly and invasion: an experimental test of neutral versus niche processes. Proceedings of the National Academy of Sciences of the United States of America 100, 8916-8920.

FISHER, R. A. (1930). The Genetical Theory of Natural Selection. Oxford: Clarendon Press.

FitZPATRICK, B.M., JOHNSON, J.R., KUMP, D.K., SMITH, J.J., VOSS, S.R. \& SHAFFER, H.B. (2010). Rapid spread of invasive genes into a threatened native species. Proceedings of the National Academy of Sciences of the United States of America 107, 3606-3610.

Folcher, L., Bourguet, D., Thiéry, D., PéLOzuelo, L., Phalip, M., Weissenberger, A., Eychenne, N., Regnault-Roger, C. \& Delos, M. (2011). Changes in parasitoid communities over time and space: a historical case study of the maize pest Ostrinia nubilalis. PLoS One 6, e25374.

Forsyth, D. M., Wilson, D. J., Easdale, T. A., Kunstler, G., Canham, C. D., Ruscoe, W. A., Wright, E. F., MuRPhy, L., GORMLEY, A. M. \& GAXIOLA, A. (2015). Century-scale effects of invasive deer and rodents on the dynamics of forests growing on soils of contrasting fertility. Ecology Monographs 85, 157-180.

Fournier, A., PenOne, C., Pennino, M. G. \& Courchamp, F. (2019). Predicting future invaders and future invasions. Proceedings of the National Academy of Sciences, 201803456.

FRIDLEY, J.D. (2012). Extended leaf phenology and the autumn niche in deciduous forest invasions. Nature 485, 359-362.

FUNK, J.L., CLELAND, E.E., SUDING, K.N. \& ZAVALETA, E.S. (2008). Restoration through reassembly: plant traits and invasion resistance. Trends in Ecology and Evolution 23, 695-703.

GASCOIGNE, J., BereC, L., GREgory, S. \& COURChAMP, F. (2009). Dangerously few liaisons: a review of mate-finding Allee effects. Population Ecology 51, 355-372. 
GENDRON, A. D. \& MARCogliese, D. J. (2017). Enigmatic decline of a common fish parasite (Diplostomum spp.) in the St. Lawrence River: Evidence for a dilution effect induced by the invasive round goby. International Journal for Parasitology: Parasites and Wildlife 6, 402-411.

Geslin, B., Gauzens, B., Baude, M., Dajoz, I., Fontaine, C., Henry, M., Ropars, L., Rollin, O., THÉBAULT, E. \& VEREECKEN, N. J. (2017). Massively introduced managed species and their consequences for plant-pollinator interactions. In Advances in Ecological Research vol. 57 - Networks of Invasion: Empirical Evidence and Case Studies (ed. D. A. Bohan, A. J. Dumbrell and F. Massol), pp. 147-199. Academic Press.

GIDOIN C., RoQUES, L. \& BOIVIN, T. (2015). Linking niche theory to ecological impacts of successful invaders: insights from resource fluctuation-specialist herbivore interactions. Journal of Animal Ecology 84, 396-406.

GIlberT, M., GREGOIRE J.-C., Freise J.F. \& HeItLAND, W. (2004). Long-distance dispersal and human population density allow the prediction of invasive patterns in the horse chestnut leafminer Cameraria ohridella. Journal of Animal Ecology 73, 459-468.

Gillard, M., ThiÉBAut, G., Deleu, C. \& Leroy, B. (2017). Present and future distribution of three aquatic plants taxa across the world: Decrease in native and increase in invasive ranges. Biological Invasions 19, 2159-2170.

Glawe, G.A., ZaVAla, J.A., Kessler, A., VAn DAm, N.M. \& BAlDWin, I.T. (2003). Ecological costs and benefits correlated with trypsin protease inhibitor production in Nicotiana attenuata. Ecology 84, 79-90.

GLÉMIN, S. (2003). How are deleterious mutations purged ? drift versus nonrandom mating. Evolution and Development 57, 2678-2687.

GRALKa, M., STIEWE F., FARRELl F., MÖBIUS W., WAClaW B. \& HALLATSCHEK O. (2016). Allele surfing promotes microbial adaptation from standing variation. Ecology Letters 19, 889-898.

GRAYSON, K.L. \& JOHNSON D.M. (2018). Novel insights on population and range edge dynamics using an unparalleled spatiotemporal record of species invasion. Journal of Animal Ecology - Global change virtual issue, 581-593.

Groves, R. (1999). Sleeper weeds. In 12th Australian Weeds Conference, Papers and Proceedings: Weed management into the 21st century: do we know where we're going? (Bishop, A.C., Boersma, M. \& Barnes, C.D.), pp. 632-636. University of Tasmania, Tasmanian Weed Society Inc., Devonport., Hobart, Tasmania, Australia

GROveS, R.H. (2006). Are some weeds sleeping? Some concepts and reasons. Euphytica 148, 111120.

GUREVITCH, J. \& PADILLA, D.K. (2004). Are invasive species a major cause of extinctions? Trends in Ecology and Evolution 19, 470-474.

GuteKUnSt, J., ANDRIANTSOA, R., FALCKENHAYN, C., HANNA, K., SteIN, W., RASAMY, J. \& LYKO, F. (2018). Clonal genome evolution and rapid invasive spread of the marbled crayfish. Nature Ecology $\mathcal{E}$ Evolution 2, 567.

GuY-Haim, T., Hyams-Kaphzan, O., Yeruham, E., Almogi-Labin, A. \& CARlton, J.T. (2017). A novel marine bioinvasion vector: Ichthyochory, live passage through fish. Limnology and Oceanography Letters 2, 81-90. 
HAACK, R.A. (2001). Intercepted Scolytidae (Coleoptera) at US ports of entry: 1985-2000. Integrated Pest Management Review 6, 253-282.

Haeuser, E., DaWson, W., Thuiller, W., Dullinger, S., Block, S., BOSSDORF, O., CARBOni, M., CONTI, L., Dullinger, I., EsSL, F., KlONNER, G., MOSER, D., MÜNKEMÜLler, T., PAREPA M., TALluto M., V. et al. (2018). European ornamental garden flora as an invasion debt under climate change. Journal of Applied Ecology 55, 2386-2395.

Hagenblad, J., Hülskötter, J., Acharya, K.P., Brunet, J., Chabrerie, O., Cousins, S., Dar, P.A., Diekmann, M., De Frenne, P., Hermy, M., Jamoneau, A., Kolb, A., Lemke, I., Plue, J., Reshi, Z.A. et al. (2015). Low genetic diversity despite multiple introductions of the invasive plant species Impatiens glandulifera in Europe. BMC Genetics. 16, 103.

HALLETT, S.G. (2006). Dislocation from coevolved relationships: a unifying theory for plant invasion and naturalization? Weed Science, 54, 282-290.

HARRISON, R.G. \& LARSON, E.L. (2014). Hybridization, introgression, and the nature of species boundaries. Journal of Heredity 105, 795-809.

HEBERLING, J.M. \& FRIDLEY, J.D. (2013). Resource-use strategies of native and invasive plants in Eastern North American forests. New Phytologist 200, 523-533.

HEDRICK, P.W. (2013). Adaptive introgression in animals: examples and comparison to new mutation and standing variation as sources of adaptive variation. Molecular Ecology 22, 4606-4618.

HERBEn, T., MANDÁK, B., BÍMOVÁ, K. \& MÜNZBERGOVÁ, Z. (2004). Invasibility and species richness of a community: a neutral model and a survey of published data. Ecology 85, 3223-3233.

Hobbs, R. J., Arico, S., Aronson, J., Baron, J. S., Bridgewater, P., Cramer, V. A., Epstein, P. R., EWel, J. J., Klink, C. A., Lugo, A. E., Norton, D., OJima, D., Richardson, D. M., SANDERSON, E. W., VALLADARES, F., et al. (2006). Novel ecosystems: theoretical and management aspects of the new ecological world order. Global Ecology Biogeography 15, 1-7.

Hobbs, R.J., Higgs, E., Hall, C.M., Bridgewater, P., Chapin, F.S., Ellis, E.C., EwEl, J.J., HalletT, L.M., HARRIS, J., HulveY, K.B., JaCKSON, S.T., KenNEDY, P.L., KuEFFER, C., LACH, L., LANTZ, T.C. et al. (2014) Managing the whole landscape: historical, hybrid, and novel ecosystems. Frontiers in Ecology and the Environment, 12, 557-564.

HOBBS, R.J., HIGGS, E. \& HARRIS, J.A. (2009). Novel ecosystems: implications for conservation and restoration. Trends in Ecology and Evolution 24, 599-605.

HODGSON, D. J., RAINEY, P. B. \& BUCKLING, A. (2002). Mechanisms linking diversity, productivity and invasibility in experimental bacterial communities. Proceedings of the Royal Society B-Biological Sciences 269, 2277-2283.

Holm, A.K., Elameen, A., Oliver, B.W., BrandSÆTER, L.O., Fløistad, I.S., \& BruRberG, M.B. (2018). Low genetic variation of invasive Fallopia spp. in their northernmost European distribution range. Ecology and evolution 8, 755-764.

HubBell, S.P. (2001). The unified theory of biodiversity and biogeography. Princeton Univ. Press, Princeton.

HUEY, R. B., GILCHRIST, G. W., \& HENDRY, \& A. P. (2005). Using invasive species to study evolution. In Species invasions: Insights into ecology, evolution and biogeography (ed. D. F. Sax, J. J. Stachowicz and S. D. Gaines), pp. 139-164. Sinauer Associates. 
Hufbauer, R.A., FACON, B., Ravigné, V., Turgeon, J., Foucaud, J., Lee, C.E., Rey, O. \& Estoup, A. (2012). Anthropogenically induced adaptation to invade (AIAI): contemporary adaptation to human-altered habitats within the native range can promote invasions. Evolutionary Applications 5, 89-101.

Hui, C., Richardson, D.M., LANDi, P., MinOARIVElO, H.O., GARNAS, J. \& ROY, H.E. (2016). Defining invasiveness and invasibility in ecological networks. Biological Invasions 18, 971.

Jacquot, M., Tixier, P., Flores, O., Muru, D., Massol, F., Derepas, B., Chiroleu, F. \& DeGuine, J.$P$. (2017). Contrasting predation services of predator and omnivore diversity mediated by invasive ants in a tropical agroecosystem. Basic and Applied Ecology 18, 31-39.

JefFery, N. W., Bradbury, I. R., StAnley, R. R. E., Wringe, B. F., WYNGAARden, M. V., LOWEN, J. B., MCKENZIE C.H., MATHESON K., SARGENT P.S. \& DiBACCO, C. (2018). Genome-wide evidence of environmentally mediated secondary contact of European green crab (Carcinus maenas) lineages in eastern North America. Evolutionary Applications 11, 869-882.

Jeffery, N. W., DiBacco, C., VAn WyngaArden, M., Hamilton, L. C., Stanley, R. R. E., Bernier, R., FitzGerald J., Matheson K., MCKenzie C.H., RAvindran P. N., Beiko R. \& Bradbury, I. R. (2017). RAD sequencing reveals genome wide divergence between independent invasions of the European green crab (Carcinus maenas) in the Northwest Atlantic. Ecology and Evolution 7, 25132524. doi:10.1002/ece3.2872

Jeschke, J., Gomez Aparicio, L., Haider, S., Heger, T., Lortie, C.J., Pyšek, P. \& Strayer, D.L. (2012). Support for major hypotheses in invasion biology is uneven and declining. NeoBiota, 14, 1-20.

JOHNSTONE, I. (1986). Plant invasion windows: a time-based classification of invasion potential. Biological Reviews 61, 369-394.

JONES, C.G., LAWTON, J.H. \& SHACHACK, M. (1994). Organisms as ecosystem engineers. Oikos 69, 373-386.

JOSHI, J. \& VRIELING, K. (2005). The enemy release and EICA hypothesis revisited: incorporating the fundamental difference between specialist and generalist herbivores. Ecology Letters 8, 704-714.

JUROSZEK, P. \& VON TIEDEMANN A. (2015). Linking plant disease models to climate change scenarios to project future risks of crop diseases: A review. Journal of Plant Diseases and Protection 122, 3-15.

KEANE, R. M. \& CRAWLEY, M. J. (2002). Exotic plant invasions and the enemy release hypothesis. Trends in Ecology E Evolution 17, 164-170.

Keller, S. R., FieldS, P. D., BerARdi, A. E. \& TAYlOR, D. R. (2014). Recent admixture generates heterozygosity-fitness correlations during the range expansion of an invading species. Journal of Evolutionary Biology 27, 616-627.

Kelly, D. W., Paterson, R. A., Townsend, C. R., Poulin, R. \& Tompkins, D. M. (2009b). Parasite spillback: A neglected concept in invasion ecology? Ecology 90, 2047-2056.

Kimura, M., MARUYAMA, T. \& CROW, J.F. (1963). The mutation load in small populations. Genetics 48, 1303-1312.

KOLAR, C.S. \& LODGE, D.M. (2001). Progress in invasion biology: predicting invaders. Trends in Ecology and Evolution 16, 199-204.

KOPP, K. \& JOKELA, J. (2007). Resistant invaders can convey benefits to native species. Oikos 116, 295-301. 
Krause, A. E., Frank, K. A., Mason, D. M., Ulanowicz, R. E. \& Taylor, W. W. (2003). Compartments revealed in food-web structure. Nature 426, 282-285.

KuebBing, S. E., ClASSEN, A. T. \& SimberlOFF, D. (2014). Two co-occurring invasive woody shrubs alter soil properties and promote subdominant invasive species. Journal of Applied Ecology 51, 124133.

KUEFFER, C., PYŠEK, P. AND RICHARDSON, D.M. (2013). Integrative invasion science: model systems, multi-site studies, focused meta-analysis and invasion syndromes. New Phytologist 200, 615-633.

LAMBertini, C., RiIS, T., Olesen, B., ClAyTON, J.S., SORREll, B.K. \& BRIX, H. (2010). Genetic diversity in three invasive clonal aquatic species in New Zealand. BMC Genetics 11, 52.

LAmarque, L.J., LORTIE, C.J., PORTÉ, A.J. \& DelzON, S. (2015). Genetic differentiation and phenotypic plasticity in life-history traits between native and introduced populations of invasive maple trees. Biological Invasions 17, 1109-1122.

LANDE, R. (2015). Evolution of phenotypic plasticity in colonizing species. Molecular Ecology 24, 2038-2045.

LANKAU, R.A. (2012). Coevolution between invasive and native plants driven by chemical competition and soil biota. Proceedings of the National Academy of Sciences 109, 11240-11245.

LANKAU, R.A., ROGERS, W.E. \& SIEMANN, E. (2004). Constraints on the utilisation of the invasive Chinese tallow tree Sapium sebiferum by generalist native herbivores in coastal prairies. Ecological Entomology 29, 66-75.

LAPARIE, M., RENAUlt, D., LEBOUVIER, M. \& DELATTRE, T. (2013). Is dispersal promoted at the invasion front? Morphological analysis of a ground beetle invading the Kerguelen Islands, Merizodus soledadinus (Coleoptera, Carabidae). Biological Invasions 15, 1641-1648.

LARson, D.L., Bright, J.B., Drobney, P., LARson, J.L., PAlaia, N., RAbie, P.A., VACEK, S. \& Wells, D. (2013). Using prairie restoration to curtail invasion of Canada thistle: the importance of limiting similarity and seed mix richness. Biological Invasions 15, 2049-2063.

Lawson Handley, L.J., Estoup, A., Evans, D., Thomas, C., LOMBAert, E., FACON, B., A. Aebi \& Roy, H. (2011). Ecological genetics of invasive alien species. BioControl 56, 409-428.

Le Cam, S., Daguin-ThiéBAut, C., Bouchemousse, S., Engelen, A. H., MieszKowsKa, N. \& Viard, F. (2019). A genome-wide investigation of the worldwide invader Sargassum muticum shows high success albeit (almost) no genetic diversity. Evolutionary Applications 00, 1-15.

LEE, C.E. (2002). Evolutionary genetics of invasive species. Trends in Ecology E Evolution 17, 386391.

LeE, C.E., REMfERT J.L. \& GELEMBIUK, G.W. (2003). Evolution of physiological tolerance and performance during freshwater invasions. Integrative Comparative Biology 43, 439-449.

LEE, K.A. \& KLASING, K.C. (2004). A role for immunology in invasion biology. Trends in Ecology and Evolution 19, 523-529.

LefFler, A.J., James, J.J., MonACO, T.A. \& Sheley, R.L. (2014). A new perspective on trait differences between native and invasive exotic plants. Ecology 95, 298-305.

Leishman, M.R., HASLEHURST, T., ARES, A. \& BARUCH, Z. (2007). Leaf trait relationships of native and invasive plants: community- and global-scale comparisons. New Phytologist 176, 635-643. 
LEVINE, J.M., ADLER, P.B. \& YELENIK, S.G. (2004). A meta-analysis of biotic resistance to exotic plant invasions. Ecology Letters 7, 975-989.

LEVINE, J.M. \& D'ANTONIO, C.M. (1999). Elton revisited: a review of evidence linking diversity and invasibility. Oikos 87, 15-26.

Levine, J.M., VilÀ, M., ANTONiO, C.M.D., DuKes, J.S., Grigulis, K. \& LAVOREL, S. (2003). Mechanisms underlying the impacts of exotic plant invasions. Proceedings of the Royal Society of London. Series B: Biological Sciences 270, 775-781.

LiaO, C., Peng, R., LuO, Y., ZHOU, X., Wu, X., FAnG, C., Chen, J. \& LI, B. (2008). Altered ecosystem carbon and nitrogen cycles by plant invasion: a meta-analysis. New Phytologist 177, 706-714.

LINDER, C.R. \& RIESEBERG, L.H. (2004). Reconstructing patterns of reticulate evolution in plants. American Journal of Botany 91, 1700-1708.

Loeuille, N. \& LOREAU, M. (2005). Evolutionary emergence of size-structured food webs. Proceedings of the National Academy of Sciences of the United States of America 102, 5761-5766.

Lombaert, E., Guillemaud, T., Cornuet, J.-M., Malausa, T., Facon, B. \& Estoup, A. (2010). Bridgehead effect in the worldwide invasion of the biocontrol harlequin ladybird. PLoS One 5, e9743.

LONSDALE, W.M. (1999). Global patterns of plant invasions and the concept of invasibility. Ecology 80, 1522-1536.

LOZON, J.D. \& MACISAAC, H.J. (1997). Biological invasions: are they dependent on disturbance? Environmental Reviews 5, 131-144.

Lymbery A.J., Morine, M., KANANI, H.G., BeATTY, S.J. \& Morgan, D.L. (2014). Co-invaders: The effects of alien parasites on native hosts. International Journal for Parasitology: Parasites and Wildlife 3, 171-177.

MACARTHUR, R. \& LEVINS, R. (1967). The limiting similarity, convergence, and divergence of coexisting species. American Naturalist 101, 377-385.

MACDOUgalL, A.S. \& TURKINGTON, R. (2005). Are exotic species the drivers or passengers of ecological change in highly disturbed plant communities? Ecology 86, 42-55.

MACel, M., De Vos, R.C.H., JANSEN, J.J., VAN DeR PUtTen, W.H. \& VAN DAM, N.M. (2014). Novel chemistry of invasive plants: exotic species have more unique metabolomic profiles than native congeners. Ecology and Evolution 4, 2777-2786.

MACK, R.N. (2003). Phylogenetic constraint, absent life forms, and preadapted alien plants: a prescription for biological invasions. International Journal of Plant Science 164, 185-196.

MACK, R.N., SimBerLofF, D., LONSDAle, W.M., Evans, H., ClOUT, M. \& BAZZAZ, F.A. (2000). Biotic invasions: causes, epidemiology, global consequences, and control. Ecological Applications 10, 689710.

MACKAY, J.W.B., RuSSEL, J.C., ClOUT, M.N., MuRHPY, E.C. \& HAUBER M.E. (2019). See how they run: Increased ranging behavior counters potential Allee effects in experimentally introduced house mice on an island. Biological Invasions 21, 1669-1681.

MANGLA, S., INDERJIT \& CALLAWAY, R. M. (2008). Exotic invasive plant accumulates native soil pathogens which inhibit native plants. Journal of Ecology 96, 58-67. 
MARLER, M., ZABINSKI C.A. \& CALLAWAY, R.M. (1999). Mycorrhizae indirectly enhance competitive effects of an invasive forb on a native bunchgrass. Ecology 80, 1180-1186.

MASCARO, J., HARriS, J.A., LACH, L., ThOMPSON, A., PERRING, M.P., RichaRdSON, D.M. \& ElLIS, E.C. (2013). Origins of the novel ecosystems concept, In Novel ecosystems: intervening in the new ecological world order (ed. R.J. Hobbs, E.S. Higgs and C.M. Hall), pp. 45-57. Wiley, Chichester.

MASSOL, F. \& CHEPTOU, P.-O. (2011a). Evolutionary syndromes linking dispersal and mating system: The effect of autocorrelation in pollination conditions. Evolution 65, 591-598.

MASSOL, F. \& CHEPTOU, P.-O. (2011b). When should we expect the evolutionary association of selffertilization and dispersal? Evolution 65, 1217-1220.

Mealor, B. A. \& HiLD, A. L. (2007). Post-invasion evolution of native plant populations: a test of biological resilience. Oikos 116, 1493-1500.

Médoc, V., Firmat, C., Sheath, D. J., PegG, J., Andreou, D. \& Britton, J. R. (2017). Chapter One Parasites and biological invasions: predicting ecological alterations at levels from individual hosts to whole networks. In Advances in Ecological Research vol. 57 - Networks of Invasion: Empirical Evidence and Case Studies (ed. D. A. Bohan, A. J. Dumbrell and F. Massol), pp. 1-54. Academic Press.

Melbourne, B.A., Cornell, H.V., Davies, K.F., DugaW, C.J., Elmendorf, S., Freestone, A.L., Hall, R.J., Harrison, S., Hastings, A., Holland, M., HolyoaK, M., LAMbrinOS, J., MOORE, K. \& YOKOMIZO, H. (2007). Invasion in a heterogeneous world: resistance, coexistence or hostile takeover? Ecology Letters 10, 77-94.

Mesgaran, M.B., Lewis, M.A., Ades, P.K., DonOhue, K., OHADI, S., LI, C. \& Cousens, R.D. (2016). Hybridization can facilitate species invasions, even without enhancing local adaptation. Proceedings of the National Academy of Sciences 113, 10210-10214.

MESSAGER, M.L. \& OLDEN, J.L. (2019). Phenotypic variability of rusty crayfish (Faxonius rusticus) at the leading edge of its riverine invasion. Freshwater Biology 64, 1196-1209.

Miranda, R.J., Coleman, M.A., Tagliafico, A., RAngel, M.S., MAmo, L.T., BARros, F. \& Kelahere, B. (2019). Invasion-mediated effcts on marine trophic interactions in a changing climate: positive feedbacks favour kelp persistence. Proceedings of the Royal Society B 286.

Mollot, G., PANTEl, J.H. \& RomanuK, T. N. (2017). The effects of invasive species on the decline in species richness: A global meta-analysis. In Advances in Ecological Research vol. 56 - Networks of Invasion: A Synthesis of Concepts (ed. D. A. Bohan, A. J. Dumbrell and F. Massol), pp. 61-83. Academic Press.

MORRIS, A., BÖRGER L. \& CROOKS E. (2019). Individual variability and invasion speed. Mathematics 7,795 .

MÜLLER-SCHÄRER, H., SCHAFFNER, U. \& STEINGER, T. (2004). Evolution in invasive plants: implications for biological control. Trends in Ecology and Evolution 19, 417-422.

MURPHY, G.E.P. \& ROMANUK, T.N. (2014). A meta-analysis of declines in local species richness from human disturbances. Ecology and Evolution, 4, 91-103.

NeI, M., MARUYAMA, T. \& CHAKRABORTY, R. (1975). The bottleneck effect and genetic variability in populations. Evolution 29, 1-10.

ORDONEZ, A., Wright, I.J. \& OlfF, H. (2010). Functional differences between native and alien species: a global-scale comparison. Functional Ecology 24, 1353-1361. 
PALACIO-LÓPEZ, K. \& GIANOLI, E. (2011). Invasive plants do not display greater phenotypic plasticity than their native or non-invasive counterparts: a meta-analysis. Oikos 120, 1393-1401.

PANNEll, J.R., Auld, J.R., Brandvain, Y., Burd, M., BusCh, J.W., ChePtOU, P.-O., CONNER, J.K., GoldBerG, E.E., Grant, A.-G., GrossenbaCHER, D.L., HoviCK, S.M., IGIC, B., KAlisz, S., PETANIDOU, T., RANDLE, A.M., et al. (2015). The scope of Baker's law. New Phytologist 208, 656-667.

Pantel, J. H., Bohan, D. A., Calcagno, V., David, P., DuyCK, P. F., Kamenova, S., Loeullle, N., Mollot, G., ROMANUK, T. N., ThÉBAUlt, E., Tixier, P. \& MASSOL, F. (2017). 14 questions for invasion in ecological networks. In Advances in Ecological Research vol. 56 - Networks of Invasion: A Synthesis of Concepts (ed. D. A. Bohan, A. J. Dumbrell and F. Massol), pp. 293-340. Academic Press.

PARKER, J.D. \& HAY, M.E. (2005). Biotic resistance to plant invasions? Native herbivores prefer nonnative plants. Ecology Letters 8, 959-967.

PARKer, I.M., Simberloff, D., LONSDAle, W.M., GoOdell, K., WONHAM, M., Kareiva, P.M., Williamson, M.H., Von Holle, B., MOYle, P.B., Byers, J.E. \& GoldWASser, L. (1999). Impact: toward a framework for understanding the ecological effects of invaders. Biological Invasions 1, 319.

Patiño, J., WhitTaker, R.J., Borges, P.A.V., Fernández-Palacios, J.M., Ah-Peng, C., Araújo, M.B., Ávila, S.P., CARdoso, P., CORnuAult, J., DE Boer, E.J., De NASCiMENTO, L., Gil, A., GonZÁleZCASTRO, A., GRUNER, et al. (2017). A roadmap for island biology: 50 fundamental questions after 50 years of The Theory of Island Biogeography. Journal of Biogeography 44, 963-983.

Perrings, C., DeHnEn-Schmutz, K., TOUZA, J. \& Williamson, M. (2005). How to manage biological invasions under globalization. Trends in Ecology and Evolution 20, 212-215.

Petit, R.J., BodÉnès, C., Ducousso, A., Roussel, G. \& KREMER A. (2004). Hybridization as a mechanism of invasion in oaks. New Phytologist 161, 151-164.

PetrovsKII, S., MOROzOV, A. \& LI, B.-L. (2005). Regimes of biological invasion in a predator-prey system with the Allee effect. Bulletin of Mathematical Biology 67, 637-661.

Petruzzella, A., Manschot, J., van Leeuwen, C.H., Grutters, B. \& BaKker, E.S. (2018). Mechanisms of invasion resistance of aquatic plant communities. Frontiers in Plant Science $\mathbf{9}, 134$.

PHILLIPS, B.L. \& PERKINS, T.A. (2019). Spatial sorting as the spatial analogue of natural selection. Theoretical Ecology 12, 155.

PhILLIPS, B.L., BROWN, G.P. \& SHINE, R. (2010). Evolutionarily accelerated invasions: the rate of dispersal evolves upwards during the range advance of cane toads. Journal of Evolutionary Biology 23, 2595-2601.

PhilliPS, B.L., BROWN, G.P., WEBB, J.K. \& SHINE, R. (2006). Invasion and the evolution of speed in toads. Nature 439, 803-803.

Pigliucci, M., Murren, C.J. \& SCHLiChting, C.D. (2006). Phenotypic plasticity and evolution by genetic assimilation. Journal of Experimental Biology 209, 2362-2367.

Pinzone, P., PotTs, D., Pettibone, G. \& WARrenII, R. (2018). Do novel weapons that degrade mycorrhizal mutualisms promote species invasion? Plant Ecology 219, 539-548.

PORTAles-Reyes, C., VAN DOORNIK, T., Schultheis, E.H. \& SUWA, T. (2015). A novel impact of a novel weapon: allelochemicals in Alliaria petiolata disrupt the legume-rhizobia mutualism. Biological Invasions 17, 2779-2791. 
Potgieter, L. J., Wilson, J. R., STRASBERG, D. \& RiCHARDSON, D. M. (2014). Casuarina invasion alters primary succession on lava flows on La Réunion Island. Biotropica 46, 268-275.

Power, G. A. \& MitcheLL, C.E. (2004). Pathogen spillover in disease epidemics. American Naturalist 164, S79-S89.

Poyet, M., Eslin, P., Heraude, M., Le Roux, V., Prevost, G., Gibert, P. \& Chabrerie, O. (2014). Invasive host for invasive pest: when the Asiatic cherry fly (Drosophila suzukii) meets the American black cherry (Prunus serotina) in Europe. Agricultural and Forest Entomology 16, 251-259.

Poyet, M., Le Roux, V., Gibert, P., Meirland, A., Prévost, G., Eslin, P. \& Chabrerie, O. (2015). The wide potential trophic niche of the asiatic fruit fly Drosophila suzukii: the key of its invasion success in temperate Europe? PLoS One 10, e0142785.

Poyet, M., Eslin, P., Chabrerie, O., Prud’homme, S. M., Desouhant, E. \& Gibert, P. (2017). The invasive pest Drosophila suzukii uses trans-generational medication to resist parasitoid attack. Scientific Reports 7, 43696.

Prentis, P.J., Wilson, J.R., DormontT, E.E., Richardson, D.M. \& LOWE, A.J. (2008). Adaptive evolution in invasive species. Trends in Plant Science 13, 288-294.

Prevosti, A., Ribo, G., Serra, L., Aguade, M., Balaña, J., Monclus, M. \& Mestres, F. (1988). Colonization of America by Drosophila subobscura: experiment in natural populations that supports the adaptive role of chromosomal-inversion polymorphism. Proceedings of the National Academy of Sciences 85, 5597-5600.

PYŠEK, P. \& PRACH, K. (1993). Plant invasions and the role of riparian habitats - a comparison of four species alien to central Europe. Journal of Biogeography 20, 413-420.

PYŠEK, P. \& RICHARDSON, D.M. (2007). Traits associated with invasiveness in alien plants: where do we stand? In Biological Invasions (ed. Nentwig, W.), pp. 97-125. Springer, Berlin-Heidelberg.

RENAULT, D., LAPARIE M., MCCAULEY S.J. \& BONTE D. (2018). Environmental adaptations, ecological filtering, and dispersal central to insect invasions. Annual Review of Entomology 63, 345-368.

ReINHART, K.O. \& CAllaWAY, R.M. (2006). Soil biota and invasive plants. New Phytologist 170, 445457.

ReISNer, M.D., GRACE, J.B., PYKe, D.A. \& DOESChER, P.S. (2013). Conditions favouring Bromus tectorum dominance of endangered sagebrush steppe ecosystems. Journal of Applied Ecology 50, 1039-1049.

REJMÁNEK, M. \& RichARDSON, D.M. (1996). What attributes make some plant species more invasive? Ecology 77, 1655-1661.

Rey, O., Estoup, A., Vonshak, M., Loiseau, A., Blanchet, S., CAlcaterra, L., Chifflet, L., Rossi, J.P., KERGOAT, G.J. \& FOUCAUD, J. (2012). Where do adaptive shifts occur during invasion? A multidisciplinary approach to unravelling cold adaptation in a tropical ant species invading the Mediterranean area. Ecological Letters 15, 1266-1275.

Ricciardi, A., HoOpeS, M.F., MARChetTI, M.P. \& LOCKWOOD, J.L. (2013). Progress toward understanding the ecological impacts of nonnative species. Ecological Monographs 83, 263-282.

RICCIARDI, A. \& MACISAAC, H.J. (2000). Recent mass invasion of the North American Great Lakes by Ponto-Caspian species. Trends in Ecology and Evolution 15, 62-65. 
Richards, C.L., Bossdorf, O., Muth, N.Z., GureVitCH, J. \& PigliuCCI, M. (2006). Jack of all trades, master of some? On the role of phenotypic plasticity in plant invasions. Ecology Letters 9, 981-993.

RICHARDSON, D.M. \& GAERTNER, M. (2013). Plant invasions as builders and shapers of novel ecosystems, in Novel Ecosystems: Intervening in the New Ecological World Order (ed. R.J. Hobbs, E.S. Higgs, and C.M. Hall), pp. 102-113. Wiley-Blackwell, Oxford, UK.

Richardson, D.M., IPOngA, D.M., Roura-PAscual, N., KRug, R., Thuiller, W., Milton, S.J. \& HUGHES, G.O. (2010). Accommodating scenarios of climate change and management in modelling the distribution of the invasive tree Schinus molle in South Africa. Ecography 33, 1049-1061

RICHARDSON, D.M. \& PYŠEK, P. (2006). Plant invasions: merging the concepts of species invasiveness and community invasibility. Progress in Physical Geography 30, 409-431.

Richardson, D.M., PYŠEK, P., \& CARLTON, J.T. (2011). A compendium of essential concepts and terminology in biological invasions. In Fifty years of invasion ecology: the legacy of Charles Elton (ed. D.M. Richardson), pp. 409-420. Wiley-Blackwell, Oxford, UK.

RiESEBERG, L.H., RAYMOND, O., ROSENTHAL, D.M., LAI, Z., LiVINGSTONE, K., NAKAZATO, T., DurPHY, J.L., SCHWARZBACH, A.E., DONOVAN, L.A. \& LEXER, C. (2003). Major ecological transitions in wild sunflowers facilitated by hybridization. Science 301, 1211-1216.

RIUS, M. \& DARLING, J.A. (2014). How important is intraspecific genetic admixture to the success of colonising populations? Trends in Ecology and Evolution 29, 233-242.

RiUs, M., TURON, X., Bernardi, G., VOlCKAERT, F.A. \& ViARD, F. (2015). Marine invasion genetics: from spatio-temporal patterns to evolutionary outcomes. Biological Invasions 17, 869-885.

RODRÍGUEZ, P.J. (2001). Exotic species introductions into South America: an underestimated threat? Biodiversity and Conservation 10, 1983-1996.

Romanuk, T.N., Zhou, Y., Brose, U., Berlow, E.L., Williams, R.J. \& MARTinez, N.D. (2009). Predicting invasion success in complex ecological networks. Philosophical Transactions of the Royal Society B: Biological Sciences 364, 1743-1754.

ROMANUK, T.N., ZHOU, Y., VALDOVINOS, F.S. \& MARTineZ, N.D. (2017). Chapter Five - Robustness trade-offs in model food webs: Invasion probability decreases while invasion consequences increase with connectance. In Advances in Ecological Research vol. 56 - Networks of Invasion: A Synthesis of Concepts (ed. D.A. BOHAN, A.J. DuMBrell \& F. MASSOL), pp. 263-291. Academic Press.

ROQUES, L., GARNIER, J., HAMEL, F. \& KLEIN, E.K. (2012). Allee effect promotes diversity in traveling waves of colonization. Proceedings of the National Academy of Sciences 109, 8828-8833.

Rouget, M., Robertson, M.P., Wilson, J.R., Hui, C., Essl, F., RENTERIA, J.L. \& RichARDSON, D.M. (2016). Invasion debt - quantifying future biological invasions. Diversity and Distribution 22, 445456.

SAARMAN, N.P. \& POGSON, G.H. (2015). Introgression between invasive and native blue mussels (genus Mytilus) in the central California hybrid zone. Molecular Ecology 24, 4723-4738.

SAKAI, A.K., Allendorf, F.W., HOlt, J.S., LOdGe, D.M., MOlOfSKY, J., WiTH, K.A., BAughMAN, S., Cabin, R.J., Cohen, J.E., Ellstrand, N.C., MCCAuley, D.E., O'NeIl, P., PARKer, I.M., ThOMPSON, J.N. \& WELlER, S.G. (2001). The population biology of invasive species. Annual Review of Ecology, Evolution, and Systematics 32, 305-332.

SAX, D.F. (2002). Native and naturalized plant diversity are positively correlated in scrub communities of California and Chile. Diversity and Distribution 8, 193-210. 
SAX, D.F. \& BROWN, J.H. (2000). The paradox of invasion. Global Ecology and Biogeography 9, 363-372.

SAX, D. F., STACHOWICZ, J. J., BROWN, J. H., BRUNO, J. F., DAWSON, M. N., GAINES, S. D., GROSBERG, R. K., Hastings, A., Holt, R. D., MAYField, M.M., O'CONNOR, M. I. \& RiCE, W. R. (2007). Ecological and evolutionary insights from species invasions. Trends in Ecology and Evolution 22, 465-471.

SCHAFFner, U., RidenOUR, W.M., Wolf, V.C., BASSETT, T., MÜLler, C., MÜLleR-SCHÄRER, H., SutHERLAND, S., LORTIE, C.J. \& CALLAWAY, R.M. (2011). Plant invasions, generalist herbivores, and novel defense weapons. Ecology 92, 829-835.

SCHRIEBER, K., \& LACHMUTH, S. (2017). The genetic paradox of invasions revisited: the potential role of inbreeding $\times$ environment interactions in invasion success. Biological Reviews 92, 939-952.

SCHREIBER, S.J. \& BECKMAN, N.G. (2019). Individual variation in dispersal and fecundity increases rates of spatial spread. BioRxiv, doi: https://doi.org/10.1101/702092.

Seabloom, E.W., Williams, J.W., Slayback, D., Stoms, D.M., Viers, J.H. \& Dobson, A.P. (2006). Human impacts, plant invasion, and imperiled plant species in California. Ecological Applications 16, 1338-1350.

Seebens, H., Blackburn, T.M., Dyer, E.E., Genovesi, P., Hulme, P.E., JeschKe, J.M., Pagad, S., PYŠEK, P., WINTER, M., ARIANOUTSOU, M., BACHER, S., Blasius, B., BRUNDU, G., CAPINHA, C., CELESTIGRAPOW, L. et al. (2017). No saturation in the accumulation of alien species worldwide. Nature communications 8, 14435 .

SEebens, H., SChWARTZ, N., SChupp, P.J. \& Blasius, B. (2016). Predicting the spread of marine species introduced by global shipping. Proceedings of the National Academy of Sciences 113, 5646-5651.

SHAW, A.K. \& KOKKO, H. (2015). Dispersal evolution in the presence of Allee effects can speed up or slow down invasions. American Naturalist 185, 631-639.

Shaw, A.K., KoKKO, H., Neubert, M.G. \& KupARInEn, A. (2018). Sex difference and Allee effects shape the dynamics of sex-structured invasions. Journal of Animal Ecology 87, 36-46.

SHEA, K. \& CHESSON, P. (2002). Community ecology theory as a framework for biological invasions. Trends in Ecology and Evolution 17, 170-176.

SHER, A.A. \& HYATT, L.A. (1999). The disturbed resource-flux invasion matrix: a new framework for patterns of plant invasion. Biological Invasions 1, 107-114.

SHINE, R., BROWN, G.P., \& PHILlIPS, B.L. (2011). Reply to Lee: Spatial sorting, assortative mating, and natural selection. Proceedings of the National Academy of Sciences 108, E348-E348.

SIEMANN, E. \& ROGERS, W.E. (2001). Genetic differences in growth of an invasive tree species. Ecology Letters 4, 514-518.

SimberlofF, D. (2004). A rising tide of species and literature: a review of some recent books on biological invasions. BioScience, 54, 247-254.

SimberlofF, D. (2009). The role of propagule pressure in biological invasions. Annual Review of Ecology, Evolution, and Systematics 40, 81-102.

Simberloff, D., MARTin, J.-L., Genovesi, P., MARis, V., WARdle, D.A., ARONSON, J., CourChamp, F., Galil, B., García-Berthou, E., PAscal, M., PYŠEK, P., SOUSA, R., TABAcchi, E. \& VilÀ, M. (2013). Impacts of biological invasions: what's what and the way forward. Trends in Ecology and Evolution 28, 58-66. 
SimberlofF, D. \& VitUle J.R.S. (2014). A call for an end to calls for the end of invasion biology. Oikos, 123, 408-413.

SIMBERLOFF, D. \& VON HOLLE, B. (1999). Positive interactions of nonindigenous species: invasional meltdown? Biological Invasions 1, 21-32.

SLATKIN, M. \& EXCOFFIER, L. (2012). Serial founder effects during range expansion: A spatial analog of genetic drift. Genetics 191, 171-181.

Sol, D., Maspons, J., Vall-Llosera, M., Bartomeus, I., García-Peña, G.E., Piñol, J. \& FRECKLETON, R.P. (2012). Unraveling the life history of successful invaders. Science 337, 580-583.

SOL, D., VILÀ M. \& KÜHN, I. (2008). The comparative analysis of historical alien introductions. Biological Invasions 10, 1119-1129.

Stachowicz, J. \& Tilman, D. (2005). Species invasions and the relationships between species diversity, community saturation, and ecosystem functioning. In Species Invasions: Insights into Ecology, Evolution, and Biogeography (ed. D. F. Sax, J. J. Stachowicz and S. D. Gaines), pp. 41-64. Sinauer Associates, inc. Sunderland, Massachusetts.

STARFINGER, U. (1997). Introduction and naturalization of Prunus serotina in central Europe. In Plant invasions: studies from North America and Europe (ed. Brock, J. H., Wade, M., Pyšek, P., Green, D.), pp. 161-171. Backhuys, Leiden.

Steeves, T. E., Maloney, R. F., Hale, M. L., Tylianakis, J. M. \& Gemmell, N. J. (2010). Genetic analyses reveal hybridization but no hybrid swarm in one of the world's rarest birds. Molecular Ecology 19, 5090-5100.

STIERS, I., COUSSEMENT, K. \& TRIEST, L. (2014). The invasive aquatic plant Ludwigia grandiflora affects pollinator visitants to a native plant at high abundances. Aquatic Invasions 9, 357-367.

StOHLGREN, T.J., BinKLeY, D., CHONG, G.W., KALKHAN, M.A., SCHELl, L.D., BULL, K.A., OTSUKI, Y., NEWMAN, G., BASHKIN, M. \& SON, Y. (1999). Exotic plant species invade hot spots of native plant diversity. Ecological Monographs 69, 25-46.

Straube, D., Johnson, E.A., PARKInson, D., SCHEU, S. \& Eisenhauer, N. (2009). Nonlinearity of effects of invasive ecosystem engineers on abiotic soil properties and soil biota. Oikos 118, 885-896.

STRAUSS, S. Y., LAU, J. A. \& CARROLL, S. P. (2006). Evolutionary responses of natives to introduced species: what do introductions tell us about natural communities? Ecology Letters 9, 357-374.

StRAUSS, A., White, A. \& BOOTS, M. (2012). Invading with biological weapons: the importance of disease-mediated invasions. Functional Ecology 26, 1249-1261.

STREICKER, D.G., TURMELLE, A.S., VONHOF, M.J., KUZMIN, I.V., MCCRACKEN, G.F. \& RUPPRECHT, C.E. (2010). Host phylogeny constrains cross-species emergence and establishment of rabies virus in bats. Science 329, 676-679.

SulliVAN, L.L., LI, B., MilLER, T.E.X., NeuberT, M.G. \& SHAW, A.K. (2017). Density dependence in demography and dispersal generates fluctuating invasion speeds. Proceedings of the National Academy of Sciences 114, 5053-5058.

SzÚCS, M., VAhsen, M.L., Melbourne, B.A., Hoover, C., Weiss-Lehman, C. \& Hufbauer R.A. (2017). Rapid adaptive evolution in novel environments acts as an architect of population range expansion. Proceedings of the National Academy of Sciences of the United States of America 114, 1350113506. 
TABASSUM, S. \& LEISHMAN, M.R. (2018). Have your cake and eat it too: greater dispersal ability and faster germination towards range edges of an invasive plant species in eastern Australia. Biological Invasions 20, 1199-1210.

Tayeh, A., Hufbauer, R.A., Estoup, A., Ravigné, V., Frachon, L. \& FACON, B. (2015). Biological invasion and biological control select for different life histories. Nature Communications 6, 7268.

TAYLOR, C.M. \& HASTINGS, A. (2005). Allee effects in biological invasions. Ecology Letters 8, 895-908.

THIÉBAUT G. (2005). Does competition for phosphate supply explain the invasion pattern of Elodea species? Water Research 39, 3385-3393.

Thorpe, A.S., Thelen, G.C., DiACONU, A., CAllawAy \& R.M. (2009). Root exudate is allelopathic in invaded community but not in native community: field evidence for the novel weapons hypothesis. Journal of Ecology 97, 641-645.

Thuiller, W., Richardson, D. M., Rouget, M., ProcheŞ, Ş. \& Wilson, J. R. U. (2006). Interactions between environment, species traits, and human uses describe patterns of plant invasions. Ecology 87, 1755-1769.

TILMAN, D. (1997). Community invasibility, recruitment limitation, and grassland biodiversity. Ecology 78, 81-92.

TILMAN, D. (2004). Niche tradeoffs, neutrality, and community structure: a stochastic theory of resource competition, invasion, and community assembly. Proceedings of the National Academy of Sciences of the United States of America 101, 10854-10861.

Tobin, P.C., Robinet, C., JOHNSON, D.M., WhitMiRe, S.L., BJøRnSTAD, O.N. \& LiEBHOLD, A.M. (2009). The role of Allee effects in gypsy moth, Lymantria dispar (L.), invasions. Population Ecology 51, 373384 .

Todesco, M., Pascual, M.A., OWens, G.L., OsteviK, K.L., MoYers, B.T., HüBner, S., Heredia, S.M., HAHN, M.A., CASEY, C., BOCK, D.G. \& RIESEBERG, L.H. (2016). Hybridization and extinction. Evolutionary Applications 9, 892-908.

TOMPKINS, D.M., WHITE, A.R. \& BOOTS, M. (2003). Ecological replacement of native red squirrels by invasive greys driven by disease. Ecology Letters 6, 189-196.

Torchin, M. E., LAfFerty, K. D., DOBSON, A. P., MCKenZIE, V. J. \& KuRIS, A. M. (2003). Introduced species and their missing parasites. Nature 421, 628-630.

TRAVIS, J.M.J. \& DYTHAM, C. (2002). Dispersal evolution during invasions. Evolutionary Ecology Research 4, 1119-1129.

Travis, J.M.J., MÜNKemüller, T. \& Burton, O.J. (2010). Mutation surfing and the evolution of dispersal during range expansions. Journal of Evolutionary Biology 23, 2656-2667.

TREWICK, S.A., MORGAN-RichardS, M. \& CHAPMAN, H.M. (2004). Chloroplast DNA diversity of Hieracium pilosella (Asteraceae) introduced to New Zealand: reticulation, hybridization, and invasion. American Journal of Botany 91, 73-85.

Urban, M.C., Bocedi, G., Hendry, A. P., Mihoub, J.-B., Pe’er, G., Singer, A., Bridle, J.R., Crozier, L. G., De Meester, L., Godsoe, W., Gonzalez, A., Hellmann, J.J., Holt, R.D., Huth, A., JOHST, et al. (2016). Improving the forecast for biodiversity under climate change. Science 353. 
VANDERHOeVen, S., Brown, C.S., Tepolt, C.K., Tsutsui, N.D., VANPARYS, V., AtKinson, S., MAhY, G. \& MONTY, A. (2010). Perspective: Linking concepts in the ecology and evolution of invasive plants: network analysis shows what has been most studied and identifies knowledge gaps. Evolutionary Applications 3, 193-202.

Van Kleunen, M.V., Dawson, W., Schlaepfer, D., JeschKe, J.M. \& Fischer, M. (2010). Are invaders different? A conceptual framework of comparative approaches for assessing determinants of invasiveness. Ecology Letters 13, 947-958.

VAN KLEUnEN, M.V., \& FISCHER, M. (2005). Constraints on the evolution of adaptive phenotypic plasticity in plants. The New Phytologist 166, 49-60.

VAN KLEUNEN, M.V. \& JOHNSON, S.D. (2007) Effects of self-compatibility on the distribution range of invasive European plants in North America. Conservation Biology 21, 1537-1544.

Van Kleunen, M.V., Manning, J.C., Pasqualetto, V. \& Johnson, S.D. (2008). Phylogenetically independent associations between autonomous self-fertilization and plant invasiveness. American Naturalist 171, 195-201.

VEIT, R.R. \& LEWIS, M.A. (1996). Dispersal, population growth, and the Allee effect: dynamics of the house finch invasion of eastern North America. American Naturalist 148, 255-274.

VERMEIJ, G.J. (1991). When biotas meet: understanding biotic interchange. Science 253, 1099-1104.

VIARD, F., DAVID, P. \& DARLING, J. A. (2016). Marine invasions enter the genomic era: three lessons from the past, and the way forward. Current zoology 62, 629-642.

VILCINSKAS, A. (2015). Pathogens as biological weapons of invasive species. PLoS Pathogens 11, e1004714.

VilcinsKAS, A., MuKHERJEe, K. \& Vogel, H. (2013). Expansion of the antimicrobial peptide repertoire in the invasive ladybird Harmonia axyridis. Proceedings of the Royal Society of London B: Biological Sciences 280.

WANG, J., GE, Y., ZHANG, C.B., BAI, Y. \& DU, Z.K. (2013). Dominant functional group effects on the invasion resistance at different resource levels. PLoS One 8, e77220.

WARDLE, D.A. (2001). Experimental demonstration that plant diversity reduces invasibility evidence of a biological mechanism or a consequence of sampling effect? Oikos 95, 161-170.

WARES, J.P., HugheS, A.R. \& GROSBERG, R.K. (2005). Mechanisms that drive evolutionary change: insights from species introductions and invasions. In Species Invasions: Insights into Ecology, Evolution, and Biogeography (Sax, D.F. et al., eds), pp. 229-257, Sinauer.

WEINSTEIN, S.B. \& LAFFERTY, K. D. (2015). How do humans affect wildlife nematodes? Trends in Parasitology 31, 222-227.

Weiss-Lehman, C., HufBauer, R.A. \& Melbourne B.A. (2017). Rapid trait evolution drives increased speed and variance in experimental range expansions. Nature Communications 8, 14303.

Wells, K., O'HARA, R.B., MORAND, S., LESSARD, J.-P. \& RiBAS, A. (2015). The importance of parasite geography and spillover effects for global patterns of host-parasite associations in two invasive species. Diversity and Distributions 21, 477-486.

WHITE, S.R., BAO, T., BENNETT, J.A., BORK, E.W. \& CAHILL JR., J.F. (2013). Using structural equation modelling to test the passenger, driver and opportunist concepts in a Poa pratensis invasion. Oikos 122, 377-384. 
Whitlock, M.C., PhILliPS, P.C., MOORE, F.B.G., \& TONSOR, S.J. (1995). Multiple fitness peaks and epistasis. Annual Review of Ecology and Systematics 26, 601-629.

WILES, G.J., BART, J., BECK, R.E. \& AGUON, C. F. (2003). Impacts of the brown tree snake: Patterns of decline and species persistence in Guam's avifauna. Conservation Biology 17, 1350-1360.

WiLli, Y.,J. VAN BUSKIRK \& A.A. HOFFMANN (2006). Limits to the adaptive potential of small populations. Annual Review of Ecology, Evolution and Systematics 37, 433-458.

WilliAmSON, M. (1996a). Biological invasions (eds Chapman \& Hall), London.

WiLliAMSON, M. (2006b). Explaining and predicting the success of invading species at different stages of invasion. Biological Invasions 8, 1561-1568.

WiLliAMSON, M. \& FITTER, A. (1996). The varying success of invaders. Ecology 77, 1661-1666.

Williams, R.J. \& MARTINEZ, N.D. (2000). Simple rules yield complex food webs. Nature 404, 180183.

YANNELLI, F.A., KOCH, C., JeSCHKE, J.M. \& KOLLMANN, J. (2017). Limiting similarity and Darwin's naturalization hypothesis: understanding the drivers of biotic resistance against invasive plant species. Oecologia 183, 775-784.

Yoshimura, A., KAWASAKI, K., TAKASU, F., TOGASHI, K., FutAi, K. \& SHIGESADA, N. (1999). Modeling the spread of pine wilt disease caused by nematodes with pine sawyers as vector. Ecology 80, 16911702.

YUAN, Y., WANG, B., ZHANG, S., TANG, J., TU, C., HU, S., YONG, J.W.H. \& CHEN, X. (2013). Enhanced allelopathy and competitive ability of invasive plant Solidago canadensis in its introduced range. Journal of Plant Ecology 6, 253-263.

ZOU, J., ROGERS, W.E. \& SIEMANN, E. (2008). Increased competitive ability and herbivory tolerance in the invasive plant Sapium sebiferum. Biological Invasions 10, 291-302. 


\section{Figure legend}

Figure 1: The invasion dynamics: hypotheses and concepts along the invasion timeline. Along the timeline, the above part of the scheme illustrates potential changes at the population scale of nonnative populations. The bottom part describes concomitant transformations of ecosystem subjected to invasions.

\section{Abbreviations of the concepts illustrated in figure 1 (bold characters):}

1 PRESE: A "preselection of traits" responsible of the invasive character of an exotic species can occur in its native area (Rey et al., 2012).

2 PREAD: "Preadaptation" (Mack, 2003): invasions may be facilitated by the introduction of organisms in regions displaying environmental characteristics similar to those of their native range. The recurrence of anthropogenic disturbance worldwide may also increase the frequency of contemporary adaptation to human-altered habitats (see also AIAI: "Anthropogenically Induced Adaptation to Invade", Hufbauer et al. (2012)).

3 BRIDG: Many invasions have stemmed not from the native range, but from a particularly successful invasive population, which serves as the source of colonists for remote new territories. This phenomenon was called the invasive bridgehead effect (Lombaert et al., 2010).

4 ANTHRO: The ever-increasing frequency of invasive species all over the world (Seebens et al., 2017) is strongly related to anthropochory through inter- and intra-continental exchanges (Perrings et al., 2005).

5 PROP: The "Propagule Pressure Hypothesis" (Simberloff, 2009), also known as introduction effort (Blackburn et al., 2011), combines the number of propagules introduced and the number of introduction events. It is recognized as a major determinant of establishment and further colonization success of invasive species.

6 3TENS: The " 3 tens rule": Williamson \& Fitter (1996) showed that there were statistical regularities to invasions: the statistical rule holds that 1 in 10 imported plants and animals appear in the wild (introduced or casual). The same proportional rule prevails between introduced and naturalised species, and between naturalised and invasive species (the "3 tens rule"; Williamson, 1996).

7 SINV: "Species invasiveness" resides in the performance, the originality and the plasticity of functional traits (Alpert, Bone \& Holzapfel, 2000; Pyšek \& Richardson, 2007; van Kleunen et al., 2010).

8 EINV: "Ecosystem invasibility": the successful integration of non-native organisms in the new area also depends on the characteristics of the recipient environment (Alpert, Bone \& Holzapfel, 2000; Richardson \& Pysek, 2006).

9 ELTON: According to "Elton's resistance hypothesis" (Elton, 1958; Levine \& D'Antonio, 1999), a high local diversity reduces community invasibility. 
10 CLON: Some exotic plants are unable to reproduce sexually in their invasion range (Lambertini et al., 2010). Their proliferation is almost exclusively or totally ensured by clonal multiplication, at least in the early stage of the invasion process. This apparent weakness of the lack of sexual reproduction may be converted into an advantage in the case where vegetative reproduction is more efficient to invade recipient ecosystems (Lambertini et al., 2010).

11 HTRAIT: Invasive plant species generally have higher values of performance-related traits characterizing physiology, leaf-area allocation, shoot allocation, growth rate, size, i.e. a better fitness than non-invasive plant species (van Kleunen et al., 2010).

12 OTRAIT: Compared with their native congeners, the non-native species possess "original, species-unique traits", which can contribute to their invasion potential. No functionally equivalent trait is present in the invaded ecosystem (Atallah et al., 2014; Macel et al., 2014).

13 PLASTI: According to the "phenotypic plasticity hypothesis", it is thus supposed that invasive species may have a greater plasticity in ecologically important traits than non-invasive ones, and populations of invasive species are expected to evolve greater plasticity in their invasive range compared to populations within the native range (Richards et al., 2006).

14 LIMSIM: The concept of "limiting similarity" (Abrams, 1983) states that invasive species will be unlikely to establish in a community dominated by functionally similar species because of greater niche overlap (Funk et al., 2008; MacArthur \& Levins, 1967).

15 ISH: "Increased Susceptibility Hypothesis": Native consumers may prefer exotic over native prey and consequently limit invasions (Parker \& Hay, 2005). Exotic preys have not experienced selection from these consumers and therefore lack effective defences, as formulated by the Increased Susceptibility Hypothesis (Colautti et al., 2004).

16 ERH: "Enemy Release Hypothesis" (Keane \& Crawley, 2002). By experiencing a decrease in regulation by consumers or other natural enemies, exotic species may rapidly increase in abundance and distribution.

17 BCH: The "Behavioural Constraint Hypothesis" establishes that potential consumers and competitors need behavioural adaptations before recognizing and readily consuming or outcompeting an introduced population (Lankau, Rogers \& Siemann, 2004).

18 ENH: "Empty Niche Hypothesis" Invasive species may expand into new areas by filling an 'empty niche'; i.e. occupying previously unoccupied (or unsaturated) habitats or exploiting a resource unused by local species (Stachowicz \& Tilman, 2005; Williamson, 1996 ).

19 HETE and 20 DIST: Spatio-temporal environmental heterogeneity and disturbances can promote invasions (Melbourne et al., 2007).

21 RSTR and 22 KSTR: "r-strategy" species (pioneers, opportunists, generalists) are favoured in early invasion stages and then competitively displaced by "K-strategists" in later stages (Facon et al., 2008; Duyck et al., 2007).

23 LATE: "Latency period" typically preceding population bloom of invasive species (Pyšek \& Prach, 1993).

24 PASS: The correlation between dominance of invasive species and decline of native populations does not constitute evidence that ecological changes are driven by invasive species (Didham et al., 2005). Indeed, habitat disturbances or fragmentation could have both detrimental impact on native 
population abundance and diversity while being beneficial for exotic species, then labelled as "passengers" of ecological change. This is the "Passenger model" (MacDougall \& Turkington, 2005; Chabrerie et al., 2008)

25 NEUTR: The "Neutral theory" (Hubbell, 2001; Chave, 2004), applied to invasions (Fargione et al., 2003; Herben et al., 2004; Tilman, 2004).

26 OPPO: "Opportunist model". Non-interactive communities represent an opportunity (that may ease the integration of non-native species (Chabrerie et al., 2008; White et al., 2013).

27 INBRE: Initial genetic bottleneck of incipient invasion leads to high inbreeding levels in introduced populations (van Buskirk \& Willi, 2006). Inbreeding may lead to both negative (inbreeding depression) and positive (purging) effects on the invasive success (see GPI and PURG).

28 GPI: "Genetic Paradox of Invasions": how do invasive populations manage to adapt to the novel selective pressures encountered in the introduced area despite reduced genetic diversity (Sax \& Brown, 2000; Estoup et al., 2016).

29 PURG: The mutation load is defined as the proportion by which the population fitness, or any other attribute of interest, is altered by recurrent mutation (Kimura, Maruyama \& Crowe, 1963). Consanguineous mating can "purge a part of the mutation load" and lethal mutations can also be purged in small populations (Glémin, 2003). Invasive species may benefit from this purge of homozygous deleterious alleles reducing their genetic/mutation load.

30 EICA: "Evolution of Increased Competition Ability" (Blossey \& Nötzold, 1995): because they escape natural enemies in their invasive range, non-native populations can save the energy formerly used for defence and reinvest it in growth, biomass, reproduction and competitiveness.

31 SORT: Spatial sorting, selection of individuals with high dispersal ability at the leading edge of invasion (Shine et al. 2011).

32 ALLEE: "Allee effect" (Petrovskii et al., 2005), occurring at the leading edge of invasion (Cappuccino, 2004; Davis et al., 2004).

33 DRIVE: "Driver model": invasive populations affect local diversity by using ecosystem resources and space more effectively than native ones (MacDougall \& Turkington, 2005; Chabrerie et al., 2008; White et al., 2013).

34 ENGE: Because of the great transformations imposed to invaded ecosystems, some non-native species have been termed "Invasive engineers" \{Cuddington, 2004 \#511\}.

35 NWH: "Novel Weapon Hypothesis" (Callaway \& Aschehoug, 2000; Callaway \& Ridenour, 2004). Novel weapons may include chemical and biological weapons.

36 SDH: “Shifting Defense Hypothesis" \{Müller-Schärer, 2004 \#3552;Doorduin, 2011 \#3553\}.

37 EMH: "Enhanced Mutualism Hypothesis": in contrast to native populations, some introduced plants can benefit from improved mutualisms with soil microorganisms (especially symbiotic fungi), which will increase their performance (Marler, Zabinski \& Callaway, 1999; Reinhart \& Callaway, 2006). 
38 MDH: The "Mutualism Disruption Hypothesis" predicts that invasive populations can also suppress soil mutualists in introduced ranges more aggressively than mutualists in their native ranges. (Callaway et al., 2008).

38 SPILL: "Spillover - Spillback". Non-native populations may carry their parasites, infecting local species, ('spillover'), and may also catch and amplify a part of local parasites, then constituting reservoirs for parasite transmission and acting as hosts to ultimately release them into ecosystem ('spillback') (Dasak et al., 2000, Amsellem et al. 2017).

39 CLIM: Climate changes facilitate the arrival of thermophilic non-native species and exacerbate their impacts.

40 DEBT: Invasion debt describes the time-delayed invasion of populations that are already present in a region. This invasion debt is problematic because a low invasion level at a given time does not ensure the maintenance of ecosystem integrity in the future. This concept can help to quantify the future invasion risks (Rouget et al., 2016).

41 ADMI: "Genetic admixture", i.e. the result of interbreeding between two or more previously isolated populations within a species. It generates heterozygosity and heterosis increasing species fitness (Keller et al., 2014; Lawson Handley et al., 2011).

42 HYBRID: Interspecific "hybridization" between native and invading species (Abbott, 1992; Petit et al., 2004)

43 GENO: "Genomic rearrangements", like chromosomic inversions (Prevosti et al.,1988) and polyploidy (POLY) can contribute to invasive species evolution.

44 POLY: "Polyploidization", i.e. genome duplication, in invasive species (Ainouche et al., 2009).

45 RETIC: "Reticulate evolution", a complex evolution form involving two genomic shocks: hybridization between evolutionary close native and invasive species (merger of divergent genomes), and polyploidization (whole genome duplication) Ainouche et al., 2009; Trewick, 2004). Reticulate evolution involving native and exotic species may lead to speciation (see the genus Spartina) through the creation of populations/species with various levels of polyploidy and various proportions of native and exotic genomes.

46 RADIA: "Adaptive radiation" in post-invasion events (Carroll \& Dingle, 1996).

47 SPECIA: Selection resulting in evolutionary adaptations and possibly "speciation" in invasive species (Lee, 2002).

48 DEAD: In some cases, after a period of successful proliferation and expansion, the invasion is petering out and ends his race in "an ecological and/or evolutionary deadlock".

49 MELT: The establishment of newly introduced populations is facilitated by previously introduced species. This is the concept of "Invasional meltdown" (Simberloff \& Von Holle, 1999).

50 COMBI: "New combinations" between exotic-native species and between exotic-exotic species (see example in Poyet et al., 2014). This includes new the "New Associations Hypothesis" NASS (Colautti et al., 2004): the relationships between non-native and native species can facilitate or impede the establishment of the non-native species and influence the invasion success. 
51 NOVEL: A new ecosystem with emerging properties ("Novel ecosystem" concept (Hobbs et al., 2006; Mascaro et al., 2013) applied to invasions (Richardson \& Gaertner, 2013; Simberloff, 2015)) is created by the activity of the invasive species. 